\title{
Distribution of inorganic and organic nutrients in the South Pacific Ocean - evidence for long-term accumulation of organic matter in nitrogen-depleted waters
}

\author{
P. Raimbault, N. Garcia, and F. Cerutti \\ Laboratoire de Microbiologie, Géochimie et Ecologie Marine (UMR 6117 CNRS), Centre d'Océanologie de Marseille, \\ Université de la Méditerranée, Campus de Luminy, 13288 Marseille, France
}

Received: 23 July 2007 - Published in Biogeosciences Discuss.: 30 August 2007

Revised: 6 December 2007 - Accepted: 25 January 2008 - Published: 3 March 2008

\begin{abstract}
During the BIOSOPE cruise the RV Atalante was dedicated to study the biogeochemical properties in the South Pacific between the Marquesas Islands $\left(141^{\circ} \mathrm{W}-8^{\circ} \mathrm{S}\right)$ and the Chilean upwelling $\left(73^{\circ} \mathrm{W}-34^{\circ} \mathrm{S}\right)$. Over the $8000 \mathrm{~km}$ covered by the cruise, several different trophic situations were encountered, in particular strong oligotrophic conditions in the South Pacific Gyre (SPG, between $123^{\circ} \mathrm{W}$ and $\left.101^{\circ} \mathrm{W}\right)$. In this isolated region, nitrate was undetectable between the surface and $160-180 \mathrm{~m}$ and only trace quantities $\left(<20\right.$ nmoles $\left.^{-1}\right)$ of regenerated nitrogen (nitrite and ammonium) were detected, even in the subsurface maximum. Integrated nitrate over the photic layer, which reached $165 \mathrm{~m}$, was close to zero. Despite this severe nitrogendepletion, phosphate was always present in significant concentrations $\left(\approx 0.1 \mu\right.$ moles $\left.{ }^{-1}\right)$, while silicic acid was maintained at low but classical oceanic levels $\left(\approx 1 \mu\right.$ moles $\left.1^{-1}\right)$. In contrast, the Marquesas region (MAR) to the west and Chilean upwelling (UPW) to the east were characterized by high nutrient concentrations, one hundred to one thousand fold higher than in the SPG. The distribution of surface chlorophyll reflected the nitrate gradient, the lowest concentrations $\left(0.023 \mathrm{nmoles}^{-1}\right)$ being measured at the centre of the SPG, where integrated value throughout the photic layer was very low $\left(\approx 10 \mathrm{mg} \mathrm{m}^{-2}\right)$. However, due to the relatively high concentrations of chlorophyll- $a$ encountered in the DCM $\left(0.2 \mu \mathrm{gl}^{-1}\right)$, chlorophyll- $a$ concentrations throughout the photic layer were less variable than nitrate concentrations (by a factor 2 to 5). In contrast to chlorophyll- $a$, integrated particulate organic matter $(\mathrm{POM})$ remained more or less constant along the study area $\left(500 \mathrm{mmoles} \mathrm{m}^{-2}, 60 \mathrm{mmoles}^{-2}\right.$ and 3.5 mmoles $\mathrm{m}^{-2}$ for particulate organic carbon, particulate organic nitrogen and particulate organic phosphorus,
\end{abstract}

respectively), with the exception of the upwelling, where values were two fold higher. The residence time of particulate carbon in the surface water was only 4-5 days in the upwelling, but up to 30 days in the SPG, where light isotopic $\delta^{15} \mathrm{~N}$ signal noted in the suspended POM suggests that $\mathrm{N}_{2}$-fixation provides a dominant supply of nitrogen to phytoplankton. The most striking feature was the large accumulation of dissolved organic matter (DOM) in the SPG compared to the surrounding waters, in particular dissolved organic carbon (DOC) where concentrations were at levels rarely measured in oceanic waters $\left(>100 \mu\right.$ moles $\left.^{-1}\right)$. Due to this large pool of DOM in the SPG photic layer, integrated values followed a converse geographical pattern to that of inorganic nutrients with a large accumulation in the centre of the SPG. Whereas suspended particulate matter in the mixed layer had a $\mathrm{C} / \mathrm{N}$ ratio largely conforming to the Redfield stochiometry $(\mathrm{C} / \mathrm{N} \approx 6.6)$, marked deviations were observed in this excess $\mathrm{DOM}(\mathrm{C} / \mathrm{N} \approx 16$ to 23$)$. The marked geographical trend suggests that a net in situ source exists, mainly due to biological processes. Thus, in spite of strong nitrate-depletion leading to low chlorophyll biomass, the closed ecosystem of the SPG can accumulate large amounts of C-rich dissolved organic matter. The implications of this finding are examined, the conclusion being that, due to weak lateral advection, the biologically produced dissolved organic carbon can be accumulated and stored in the photic layer for very long periods. In spite of the lack of seasonal vertical mixing, a significant part of new production (up to 34\%), which was mainly supported by dinitrogen fixation, can be exported to deep waters by turbulent diffusion in terms of DOC. The diffusive rate estimated in the SPG $\left(134 \mu\right.$ molesC $\left.\mathrm{m}^{-2} \mathrm{~d}^{-1}\right)$, was quite equivalent to the particles flux measured by sediments traps.

Correspondence to: P. Raimbault

(patrick.raimbault@univmed.fr)

Published by Copernicus Publications on behalf of the European Geosciences Union. 


\section{Introduction}

The warm oligotrophic regions of the open ocean are subject to smaller seasonal temperature variations than temperate waters, and are permanently underlain by a strong thermocline. Therefore they are regarded as the least variable and the least productive surface waters of the sea. However, as they represent $60 \%$ of the global oceanic area, the subtropical open-ocean ecosystems are the largest coherent biomes of our planet and the biogeochemical processes they support have global consequences (Karl, 2002). A comprehensive evaluation of both inorganic and organic nutrient pools is important in order to understand the production and fate of organic matter in these large oceanic areas. Rates of inorganic nutrient assimilation reported for oligotrophic waters are subject to large errors (McCarthy, 1980) as conventional nutrient analysis are unable to measure the extremely low concentrations that exist over the vast areas of the open ocean. Over the last 15 years, international programs have advanced our understanding of these vast marine ecosystems; however the South Pacific remains one of the least studied areas of the Ocean (Daneri and Quinones, 2001). This region has been described as the most oligotrophic zone in the world's oceans (Dandonneau et al., 2006) having the lowest surface chlorophyll concentrations, observed using satellite imagery (Claustre and Maritorena, 2003) and confirmed by exhibiting the clearest oceanic waters of the world (Morel et al., 2007).

The BIOSOPE (BIOgeochemistry and Optics South Pacific Experiment) cruise provided the first spatially extensive experiment in the South East Pacific. The $8000 \mathrm{~km}$ transect, stretching from the Marquesas Islands to the Chilean coast and crossing the centre of the SPG, is an ideal area for studying organic and inorganic nutrients along an extreme trophic gradient. The main objective of this work is to describe inorganic and organic distributions by comparing the different environmental conditions covered by the BIOSOPE cruise. Since ambient concentrations are often below the detection limit of conventional analytical procedures (Brzezinski, 1985; Garside 1985; Sahlsten, 1987; Raimbault et al., 1999) the more sensitive methods of Garside (1982), Raimbault et al. (1990) and Holmes et al. (1999) have to be employed in order to detect the trace nutrients. In this paper we describe spatial and vertical distributions of inorganic and organic nutrients in the South Pacific in particular in the oligotrophic SPG. Pools of carbon, nitrogen and phosphorus essential for production in the upper layer are analyzed producing the first broad data base for this unexplored oceanic region.

\section{Materials and methods}

Data was collected during the BIOSOPE cruise carried out on board the R/V Atalante between October-November
2004 in the southeast Pacific Ocean along a transect between the Marquesas archipelago and the Chilean coasts (from $146.36^{\circ} \mathrm{W}-15.24^{\circ} \mathrm{S}$ to and $72.49^{\circ} \mathrm{W}-34.7^{\circ} \mathrm{S}$, Fig. 1). Twenty four short-term $(8 \mathrm{~h})$ stations were studied during transit. In addition, six experimental sites were specifically investigated with long fixed stations (over 2-5 days), representing sites of different trophic regimes: MAR $=$ Marquesas archipelago $\left(141.3^{\circ} \mathrm{W} ; 8.4^{\circ} \mathrm{S}\right)$; HLNC=High Nutrient Low Chlorophyll area east of the Marquesas islands $\left(136.8^{\circ} \mathrm{W} ; 9^{\circ} \mathrm{S}\right) ; \mathrm{GYR}=$ centre of the South Pacific gyre $\left.114^{\circ} \mathrm{W}, 26^{\circ} \mathrm{S}\right)$; EGY=eastern border of the gyre $\left(91.4^{\circ} \mathrm{W}\right.$, $\left.31.8^{\circ} \mathrm{S}\right)$, UPW and UPX situated in the area of Chilean upwelling $\left(73^{\circ} \mathrm{W}-34^{\circ} \mathrm{S}\right.$ and $\left.72.4^{\circ} \mathrm{W}-34.5^{\circ} \mathrm{S}\right)$. Sampling sites in the gyre were selected using ocean colour images, and exhibited the lowest surface chlorophyll concentrations found in the world's oceans. High vertical resolution environmental data were collected between 0 and $500 \mathrm{~m}$ using a conductivity temperature-depth-oxygen profiler (CTDO, Seabird 911 plus) with a rosette supporting 12-1 Niskin bottles equipped with silicon rubber closures.

\subsection{Inorganic nutrients}

Nutrient samples for nitrate, nitrite, phosphate and silicic acid determination, were collected into $20 \mathrm{ml}$ polyethylene flasks and $250 \mathrm{ml}$ polycarbonate bottles at each station. Samples in the $20 \mathrm{ml}$ polyethylene flasks were immediately poisoned with mercuric chloride $\left(10 \mu \mathrm{g} \mathrm{ml}^{-1}\right)$, according to Kirkwood (1992), and stored for subsequent laboratory analysis. Ambient nitrate, nitrite and phosphate concentrations were measured immediately by pumping the $250 \mathrm{ml} \mathrm{sam}$ ple through a Technicon AutoAnalyzer®. Nitrate and nitrite concentrations in the nanomolar range (lower detection limit $=3 \mathrm{nmoles}^{-1}$ ) were obtained using the sensitive method of Raimbault et al. (1990). Nitrate at submicromolar levels (detection limit $0.05 \mu$ moles $1^{-1}$ ) and phosphate (detection limit $0.02 \mu$ moles $^{-1}$ ) were measured according to the method of Armstrong et al. (1967). Ammonium concentrations ( $40 \mathrm{ml}$ collected into $50 \mathrm{ml}$ Schott glass flasks) were measured using the sensitive method of Holmes et al. (1999) having a detection limit of 5 nmoles $1^{-1}$.

Silicic acid concentrations as well as duplicate nitrate and phosphate concentrations were determined in the laboratory (Tréguer and LeCorre, 1975) on the poisoned samples four months after sampling. To ensure the reproducibility of nutrient measurements between analyses, in-house standards were used, which were regularly compared to the commercially available products (OSIL). Precision was also tested, through participation in the European inter-calibration exercise QUASIMEME (http://www.quasimeme.org).

\subsection{Phytoplanktonic biomass}

$250 \mathrm{ml}$ of seawater was filtered through $25 \mathrm{~mm}$ Whatmann GF/F filters (nominal pore size around $0.7 \mu \mathrm{m}$ ) immediately 


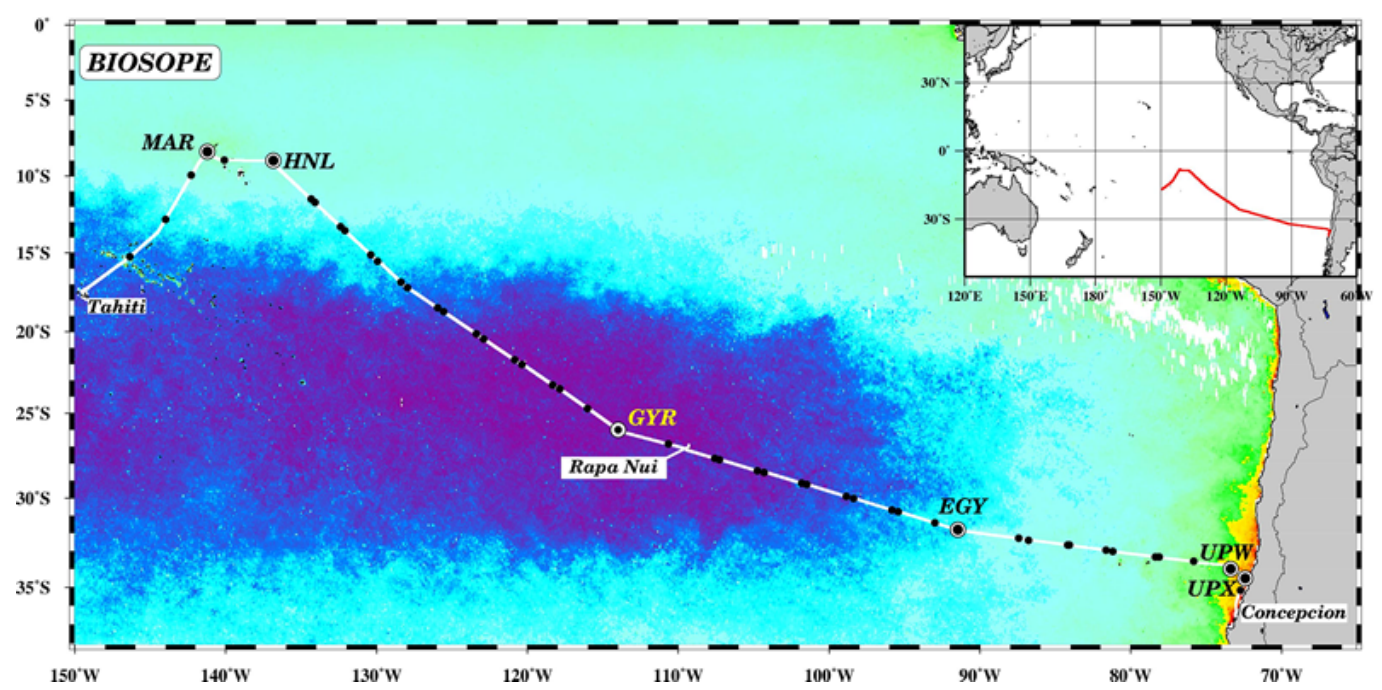

Fig. 1. Map showing the location of the BIOSOPE cruise from Marquises Island to Chile superimposed on a SeaWiFS surface Chl- $a$ composite. Locations of CTD casts are indicated by dark spots and long time experimental stations by large circles. $\left(\mathrm{MAR}=141.3^{\circ} \mathrm{W} ; 8.4^{\circ} \mathrm{S}\right.$; $\left.\mathrm{HLN}=136.8^{\circ} \mathrm{W} ; 9^{\circ} \mathrm{S} ; \mathrm{GYR}=114^{\circ} \mathrm{W}, 26^{\circ} \mathrm{S}\right)$; EGYR=eastern border of the gyre $\left(91.4^{\circ} \mathrm{W}, 31.8^{\circ} \mathrm{S} ; \mathrm{UPW}^{\circ} 73^{\circ} \mathrm{W}-34^{\circ} \mathrm{S}\right.$ and $\mathrm{UPX}=72.4^{\circ} \mathrm{W}-$ $\left.34.5^{\circ} \mathrm{S}\right)$.

Table 1. Values for reagent blanks and blank filters (not including reagent blank) obtained during the analysis of dissolved and particulate organic matter using wet oxidation or high temperature combustion.

\begin{tabular}{|c|c|c|c|c|c|}
\hline & \multicolumn{3}{|c|}{ Wet oxidation } & \multicolumn{2}{|c|}{ High temperaturecombustion } \\
\hline & $\mathrm{C}$ & $\mathrm{N}$ & $\mathrm{P}$ & & $\mathrm{N}$ \\
\hline & \multicolumn{3}{|c|}{$\mu$ moles. $1^{-1}$} & & $\mu$ moles \\
\hline Reagent blank & $5.9 \pm 0.3$ & $0.2 \pm 0.08$ & $0.03 \pm 0.01$ & & \\
\hline \multirow[t]{2}{*}{ DIW } & $4.2 \pm 0.6$ & $<$ D.L. & $<$ D.L. & & \\
\hline & \multicolumn{3}{|c|}{$\mu$ moles/filter } & \multicolumn{2}{|c|}{$\mu$ moles/filter } \\
\hline Blank filter Teflon (47 mm) & $2.2 \pm 0.85$ & $0.05 \pm 0.07$ & $0.008 \pm 0.005$ & & \\
\hline Blank filter GF/F (25 mm) & $0.63 \pm 0.18$ & $0.03 \pm 0.02$ & $0.003 \pm 0.003$ & $0.9 \pm 0.3$ & $0.13 \pm 0.05$ \\
\hline
\end{tabular}

after sampling, and placed in glass tubes containing $5 \mathrm{ml}$ of pure methanol as described by Raimbault et al. (2004). Following 20-30 min of extraction, fluorescence of the extract was determined on a Turner Fluorometer 110 equipped with the Welschmeyer kit to avoid chlorophyll- $b$ interference (Welschmeyer, 1994). As the monochromatic fluorescence method cannot separate divinyl chlorophyll from chlorophyll- $a$, results are given in terms of total chlorophyll$a$ concentration (Tchl- $a$ ), i.e. the sum of chlorophyll- $a$ and divinyl chlorophyll- $a$. The blank "methanol + filter" was close to zero giving a very low detection limit of around $0.01 \mu \mathrm{gl}^{-1}$. Calibrations were made using a pure Sigma chlorophyll- $a$ standard.

\subsection{Organic nutrients}

Samples for particulate organic carbon (POC), particulate organic nitrogen (PON) and particulate organic phospho- rus (POP) were filtered onto a $0.2 \mu \mathrm{m}$ Teflon membrane. The hydrophobic Teflon membranes were washed with $1 \mathrm{ml}$ ethanol just before filtration and then rinsed with milliQ water. Between 580 to $1200 \mathrm{ml}$ of sample was filtered, dependant on the quantity of particulate matter in the sample. Following filtration, filters were washed with $100 \mu \mathrm{l}$ of $\mathrm{H}_{2} \mathrm{SO}_{4}(0.5 \mathrm{~N})$ to remove any inorganic carbon. The filters were then stored in $25 \mathrm{ml}$ Schott glass bottles for subsequent laboratory analysis. Blank filters were prepared for each set of samples by washing the filter with $1 \mathrm{ml}$ ethanol and rinsing with $600 \mathrm{ml}$ of $<0.2 \mu \mathrm{m}$ seawater. Determination of POC, PON and POP was carried out simultaneously on the same sample using the wet-oxidation procedure according to Raimbault et al. (1999a). Filter blanks are given in Table 1. Values were slightly higher than those published by Raimbault et al. (1999a) but remain three to ten fold lower than the samples. Samples for particulate carbon (PC) and particulate nitrogen (PN) were filtered onto 
Whatman GF/F filters and values were obtained using dual isotopic ${ }^{13} \mathrm{C} /{ }^{15} \mathrm{~N}$ experiments (see Raimbault and Garcia, 2007). The filters were not acidified and PC and PN measurements were obtained using high combustion $\left(900^{\circ} \mathrm{C}\right)$ on a CN Integra mass spectrometer. Samples for total organic matter determination were collected directly from the Niskin bottles into $50 \mathrm{ml}$ Glass Schott bottles. Samples were immediately acidified with $100 \mu \mathrm{H}_{2} \mathrm{SO}_{4} 0.5 \mathrm{~N}$ and stored for analytical determination in the laboratory. Prior to oxidation, samples were bubbled with a high purity oxygen/nitrogen gas stream for $15 \mathrm{~min}$. Persulfate wet-oxidation was used to digest the organic matter in these unfiltered samples, according to Raimbault et al. (1999b). The calibration was made according to the range of the marine content observed. Total organic nitrogen and total organic phosphorus was calculated as total nitrogen and phosphorus minus dissolved inorganic nitrogen (nitrate+nitrite+ammonium) or phosphate measured in the same samples. Dissolved organic carbon (DOC), dissolved organic nitrogen (DON) and dissolved organic phosphorus (DOP) were calculated from these total organic fractions by subtracting values of POC, PON and POP obtained from the $>0.2 \mu \mathrm{m}$ fractions (see above). The analytical accuracy was close to 5, 0.5 and $0.05 \mu$ mole $^{-1}$ for DOC, DON and DOP, respectively. Deep Sargasso Sea reference water was used to verify the analytical calibration ( $45 \mu$ moles $\mathrm{C}^{-1} \pm 0.5 \mathrm{SE}$, Hansell Laboratory, Bermuda Biological Station for Research). All reagents and sample blanks were prepared using fresh Millipore Milli-Q plus ${ }^{\circledR}$ water. Mean blank values are presented in Table 1.

2.4 Natural abundance of particulate ${ }^{15} \mathrm{~N}$ measurements $\left(\delta^{15} \mathrm{~N}\right)$

Water samples were drawn into 101 polyethylene bottles and the contents filtered immediately online, onto pre-combusted Whatman, GF/F filters which were placed into glass tubes and dried at $60^{\circ} \mathrm{C}$. Some large samples (1000-1500 l) were also collected using an in situ pump and a fraction of the glass fiber filter, corresponding to 10-151 of seawater, was treated as above. In the laboratory, each filter was rolled into a pellet and fed into a mass-spectrometer (CN-Integra tracer-mass) to analyse the stable isotopic composition of the particulates $\left(\delta^{15} \mathrm{~N}\right)$. An organic standard (glycine) was used to calibrate the PN measurements and to track the consistency of the Dumas combustion. The $\delta^{15} \mathrm{~N}$ of this standard was $4.88 \pm 0.39 \%$ 。 $(n=24)$ for nitrogen levels ranging from 20 to $140 \mu \mathrm{g}$. In addition, two NIST-certified organic ${ }^{15} \mathrm{~N}$ reference materials (IAEA 310 A $\delta^{15} \mathrm{~N}=47 \%$; IAEA $310 \mathrm{~B}, \delta^{15} \mathrm{~N}=245 \%$ ) were used to insure the accuracy of the isotopic measurements. The values for these analysis were $47.3 \pm 0.27 \%$ and $243 \pm 0.46 \%$ o for AIEA310 an AIEA 310b, respectively. Analytical precision determined with these reference materials was $0.03 \%$. The standard reference was atmospheric $\mathrm{N}_{2}$ gas $\left({ }^{15} \mathrm{~N} /{ }^{14} \mathrm{~N}=0.003663: \delta^{15} \mathrm{~N}=0 \%\right.$ o) .
Surface light levels and the thickness of the euphotic layer were measured around local noon using a spectroradiometer (LI.1800U.W, LI-COR instrument; Morel et al., 2007). The depth of the euphotic zone (Ze) is defined as the depth where the downward photosynthetical available radiation (PAR) irradiance is reduced to $1 \%$ of its surface value. For CTD casts performed early in the morning, Ze was computed using in situ TChl- $a$ concentration profiles (see Ras et al., 2007) according to the model developed by Morel and Maritorena (2001).

Data shown throughout this paper are limited to the 0 $300 \mathrm{~m}$ water column.

\section{Results}

\subsection{Hydrological background}

The general distribution of temperature and salinity are presented and described in Claustre et al. (2008) and Ras et al. (2007). Briefly, surface temperature generally decreased from the Marquesas site $\left(27.8^{\circ} \mathrm{C}\right)$ to the Chilean coast $\left(18^{\circ} \mathrm{C}\right)$. Surface temperatures were greater than $25^{\circ} \mathrm{C}$ up to $125^{\circ} \mathrm{W}$ and greater than $20^{\circ} \mathrm{C}$ up to $100^{\circ} \mathrm{W}$. The $15^{\circ} \mathrm{C}$ isotherm remained below $250 \mathrm{~m}$ until $100^{\circ} \mathrm{W}$ rapidly becoming shallower thereafter and reaching the surface along the Chilean coast. Salinity patterns (Fig. 2) generally followed those of temperature, decreasing from west (37.75) to east (34.5); but a maximum (>36.5) and minimum $(<34.25)$ were noted around $130^{\circ} \mathrm{W}$ and $90^{\circ} \mathrm{W}$, respectively. These specific water masses are referred to as the South Pacific Tropical Waters (SPTW) and Eastern South Pacific Intermediate Waters (ESPIW). The waters surrounding the Marquesas Islands $\left(8^{\circ}-141^{\circ} \mathrm{W}\right)$ were influenced by the South Equatorial current and constituted the southern boundary of High Nutrient Low Chlorophyll (HNLC) waters of the equatorial upwelling region (Andrié et al., 1993). Salinity ranged from 35.5-35.7 and surface temperatures reached $27.9^{\circ} \mathrm{C}$. The Peru-Chile current, delimited by an isohaline of 34.3 was associated with fresher waters, especially between $78^{\circ} \mathrm{W}$ and $75^{\circ} \mathrm{W}$ (salinity around 34.1).

\subsection{Inorganic nutrient distribution}

The distribution of major inorganic nutrients (nitrate, phosphate and silicate) is shown in Fig. 2. In contrast to temperature, the nutrient isolines sunk deeper from west to east up until $110^{\circ} \mathrm{W}$. Thus, the concentrations of deep and surface nutrients tended to be symmetrically distributed around the center of the investigated area, with lowest concentrations found in the central region $\left(110^{\circ} \mathrm{W}\right)$. The Marquesas region (moving westward to $135^{\circ} \mathrm{W}$ ), located at the southern limit of the equatorial pacific, was characterized by rich superficial waters with nitrate concentrations greater than $1 \mu$ moles $1^{-1}$. The $2 \mu$ moles $1^{-1}$ isoline, indicated the start of the nitracline 

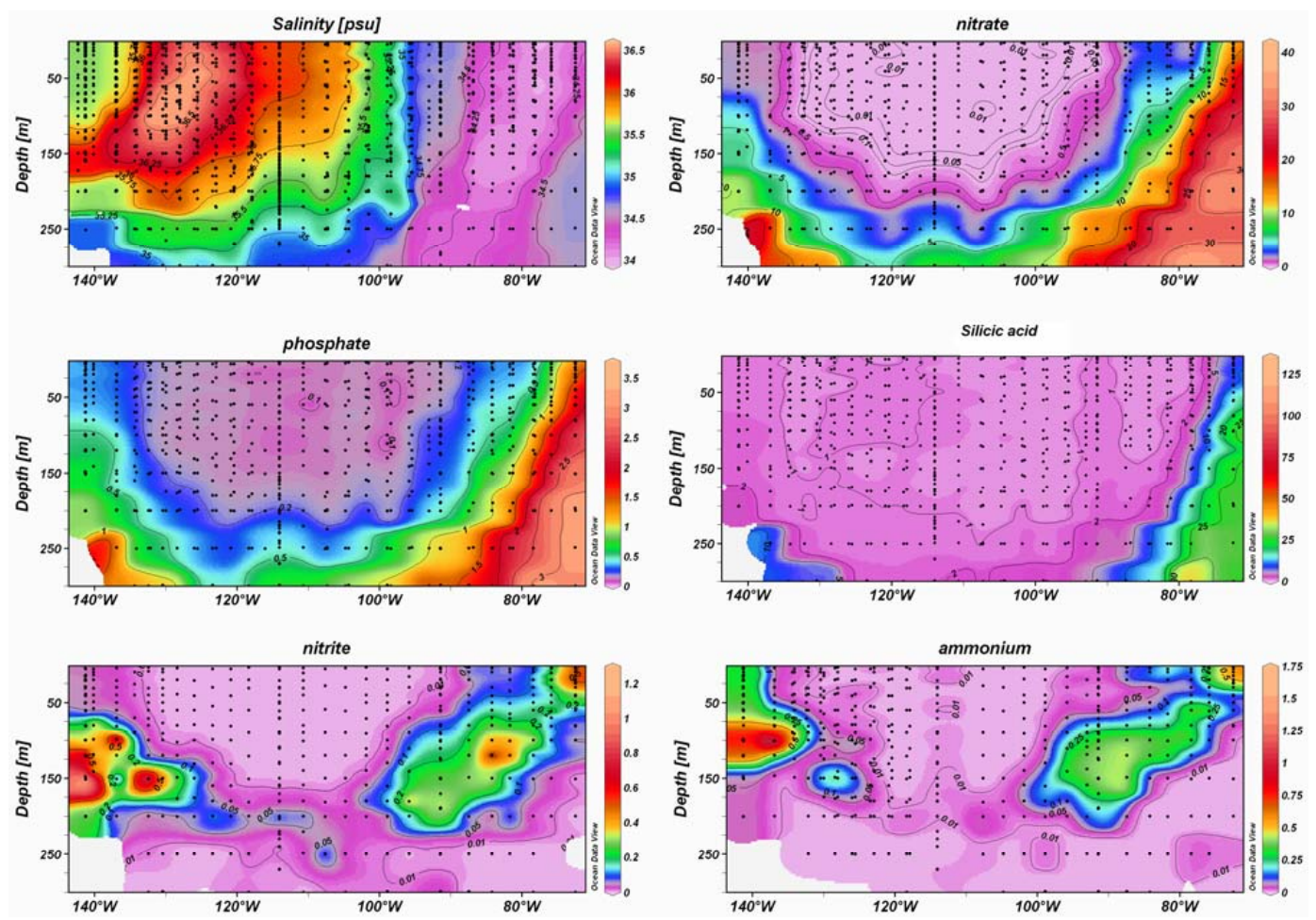

Fig. 2. Longitudinal section of salinity, nitrate, phosphate, silicic acid, nitrite and ammonium along the BIOSOPE Transect. Units for nutrients are $\mu$ moles $1^{-1}$. (Ocean Data View software (ODV), version 3.1, Reiner Schlitzer, http://odv.awi.de).

at $55 \mathrm{~m}$. Phosphate was also present in significant concentrations ranging between 0.3 and $0.5 \mu$ moles $1^{-1}$. To the east of the Marquesas island $\left(135^{\circ} \mathrm{W}\right.$ to $\left.130^{\circ} \mathrm{W}\right)$, nitrate was still detectable in the surface but there was a significant variation in the nitrate level with depth, with concentrations decreasing from 1 to $0.05 \mu$ moles $1^{-1}$ between the surface and $100 \mathrm{~m}$. Phosphate concentrations in the surface were close to $0.2 \mu$ moles $1^{-1}$. Here, the nitracline was deeper, reaching $60-70 \mathrm{~m}$. The centre of investigated area (South Pacific Gyre $=\mathrm{SPG} ; 125^{\circ} \mathrm{W}$ to $100^{\circ} \mathrm{W}$ ) was characterized by very nutrient-depleted water. Surface nitrate concentrations were always lower than $0.010 \mu$ moles $1^{-1}$ and often undetectable $\left(<0.003 \mu\right.$ moles $\left.1^{-1}\right)$ in the upper $100 \mathrm{~m}$ layer, or the upper $160 \mathrm{~m}$ layer between $120^{\circ} \mathrm{W}$ and $110^{\circ} \mathrm{W}$. Moving eastward from $108^{\circ} \mathrm{W}$, the depth at which nitrate concentrations reached $0.01 \mu$ moles $1^{-1}$ reduced, getting close to the surface at $96^{\circ} \mathrm{W}$. This defines the eastern limit of the SPG. As in the case of nitrate, surface concentrations of phosphate were minimal in the SPG $\left(\approx 0.1 \mu\right.$ moles $\left.1^{-1}\right)$. However, despite complete nitrate-depletion, surface waters were phosphatereplete over the whole transect. Further west, surface nutrient concentrations increased rapidly reaching maximum values in the Chilean upwelling region. The $5 \mu$ moles $1^{-1}$ nitrate isoline outcropped at the surface at $76^{\circ} \mathrm{W}$. This defines the western limit of the upwelling. Silicic acid distribution showed the same general pattern as that of nitrate, although surface concentrations along the transect were less variable, ranging from 1 to $2 \mu$ moles $1^{-1}$, and up to $10 \mu$ moles $1^{-1}$ in the upwelling. Concentrations were lowest in the SPG, but always close to $1 \mu$ moles $1^{-1}$. Thus, like phosphate, complete silicic acid-depletion was never observed.

Regenerated forms of nitrogen, such as nitrite and ammonium (Fig. 2), showed particular distribution patterns characterized by the presence of subsurface maxima located at each extremity of the transect. Nitrite was generally undetectable or present in very low concentrations at the surface $\left(<0.05 \mu\right.$ moles $\left.l^{-1}\right)$, except in the upwelling region where superficial concentrations reached $0.1 \mu$ moles $1^{-1}$ (up to $0.5 \mu$ moles $\left.1^{-1}\right)$. A well-marked maximum was located at $120 \mathrm{~m}$ in the western area, with concentrations reaching $0.5 \mu$ moles $1^{-1}$. This subsurface maximum disappeared in the SPG (between $120^{\circ} \mathrm{W}$ and $105^{\circ} \mathrm{W}$ ) and only some traces of nitrite $\left(<0.05 \mu\right.$ moles $\left.1^{-1}\right)$ were detected below the euphotic zone $(200 \mathrm{~m})$, associated with the $0.5 \mu$ moles $1^{-1}$ nitrate isoline. A second maximum was observed around $150 \mathrm{~m}$, from $100^{\circ} \mathrm{W}$. However, in contrast to the western maximum, nitrite concentrations rarely reached $0.5 \mu$ moles $1^{-1}$ and remained close to $0.25 \mu$ moles $1^{-1}$, except in surface upwelling waters. Whatever the depth of the nitracline (depth where nitrate ranged between 0.01 and $0.05 \mu$ mole $1^{-1}$ ), the primary nitrite maximum was about 10 to $20 \mathrm{~m}$ deeper than the top of the nitracline. 

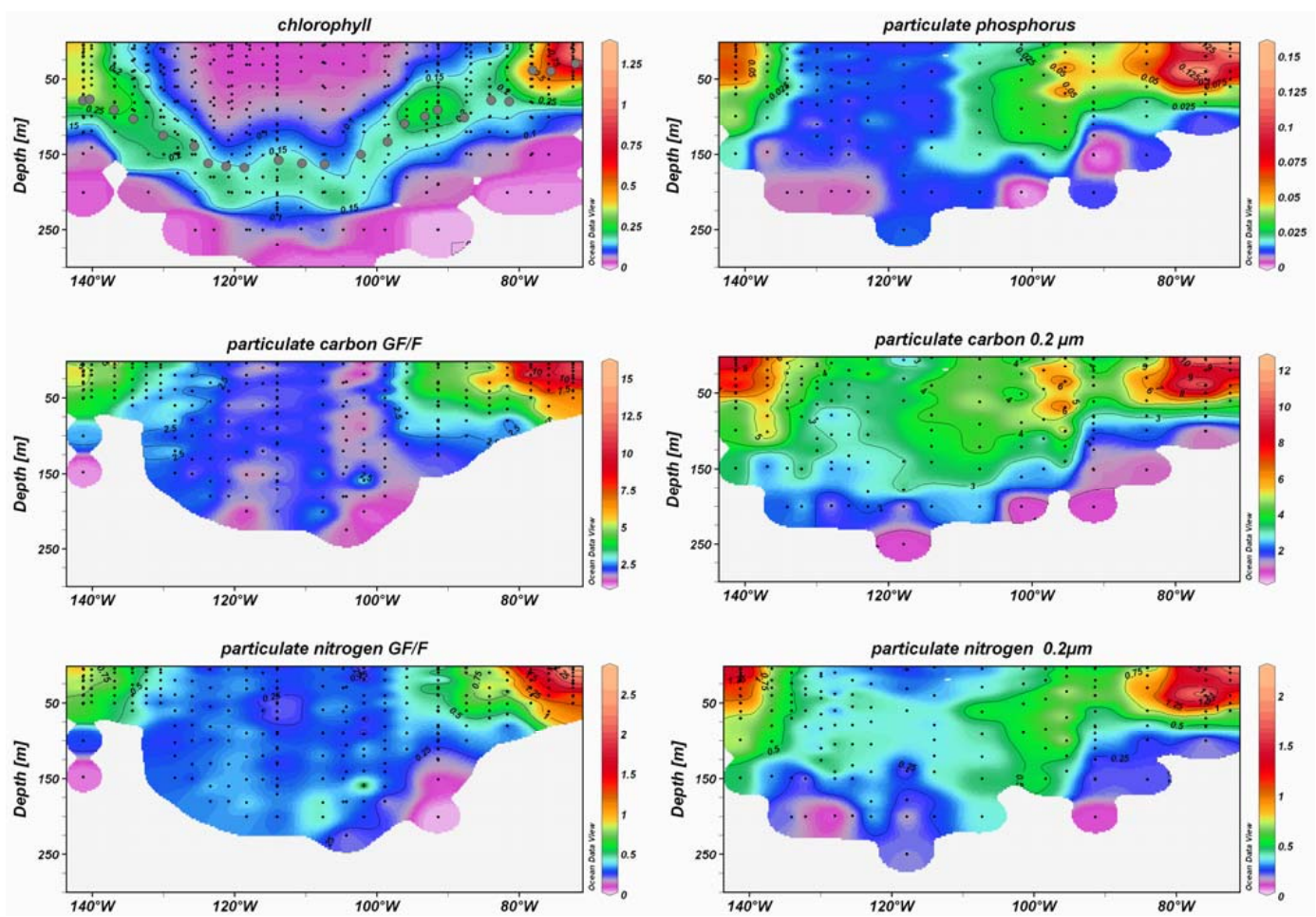

Fig. 3. Vertical sections of total chlorophyll- $a$ (Chlorophyll in $\mu \mathrm{gl}^{-1}$ ), particulate phosphorus, $>0.2 \mu$ m particulate organic carbon and particulate nitrogen and $>$ GF/F particulate carbon and particulate nigrogen (units are in $\mu$ moles $1^{-1}$ ). Dark spots on chlorophyll section indicate the 1\% light penetration depth. (Ocean Data View software (ODV), version 3.1, Reiner Schlitzer, http://odv.awi.de).

Ammonium concentrations followed the same general trend. Highest concentrations (up to $0.5 \mu$ moles $^{-1}$ ) being located in the subsurface in the Marquesas zone, although the maximum concentration was shallower than the nitrite maximum ( $100 \mathrm{~m}$ instead of $150 \mathrm{~m})$. High surface concentrations ( $>0.3 \mu$ moles $^{-1}$ ) were also measured in this region. The SPG was characterized by undetectable ammonium concentrations through most of the superficial layer. A very weak and narrow maximum, with trace concentrations of ammonium $\left(0.010 \mu\right.$ moles $\left.1^{-1}\right)$, was detected around $180 \mathrm{~m}$, more or less associated with the narrow nitrite maximum. The western ammonium maximum was also located just above the nitrite maximum. Concentrations ranged from 0.25 to $0.3 \mu$ moles $1^{-1}$. The eastern boundary of the SPG was also characterized by a deep ammonium maximum (80-100 m), with lower concentrations than those observed in the western region $\left(<0.25 \mu\right.$ moles $\left.^{-1}\right)$. The upwelling area was defined by surface concentrations $>0.25 \mu$ moles $1^{-1}$. Concentrations of both regenerated nitrogen forms followed similar trends to those of the macronutrients, with "hot spots" to the west and east of the investigated transect. The SPG was entirely Ndepleted, indicating low nitrogen regeneration activity or a tight coupling between regeneration and phytoplankton and bacteria uptake.

\subsection{Biomass distribution}

Vertical distributions of biomass are shown in Fig. 3 as total chlorophyll- $a$ (TChl- $a$ ), particulate organic carbon (POC), particulate organic nitrogen (PON) and particulate organic phosphorus (POP). In situ chlorophyll- $a$, in accordance with ocean colour imagery, showed considerable variations across the South Pacific. TChl- $a$ distribution and concentration are roughly equivalent to those found by Ras et al. (2007) who used the HPLC procedure. The extremities of the transect exhibited the highest biomass, located in the surface, while very low chlorophyll concentrations were measured at the center of the SPG. The lowest concentration $\left(0.023 \mu \mathrm{gl}^{-1}\right)$ was found in the surface at $114^{\circ} \mathrm{W}$. This value is close to the lowest measured at this site $\left(0.017 \mu \mathrm{gl}^{-1}\right)$ by Ras et al. (2007). In contrast, in the waters off the Marquesas Islands, surface Tchl- $a$ were ten folds higher $\left(0.3 \mu \mathrm{gl}^{-1}\right)$ and higher than values previously observed in the subequatorial area at other times of the year (Signorini at al., 1999). In the Chilean upwelling, surface Tchl- $a$ was much higher (up to $3 \mu \mathrm{gl}^{-1}$ ). The SPG was also characterized by a deep chlorophyll maximum (DCM) at 160 and $180 \mathrm{~m}$ between $120^{\circ} \mathrm{W}$ and $100^{\circ} \mathrm{W}$. The depth of the DCM decreased progressively eastward and westward, reaching the surface at the Chilean upwelling, but restricted to $50 \mathrm{~m}$ in the Marquesas area. While the DCM was generally found just above the $1 \%$ light penetration depth in 

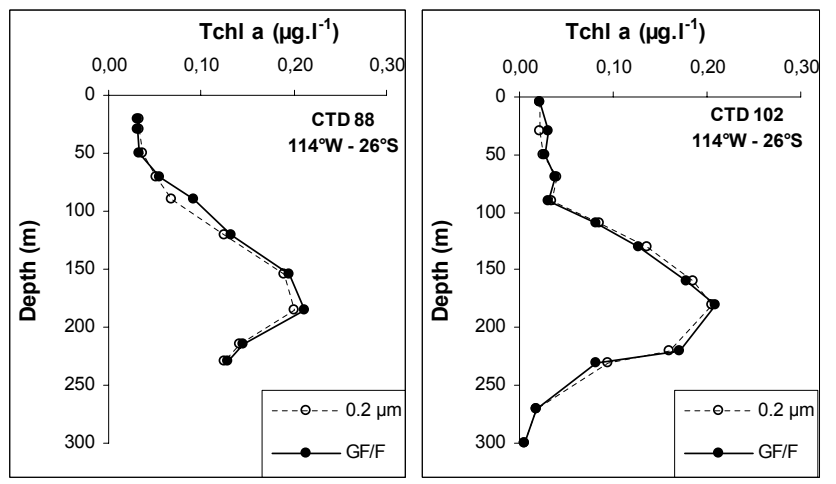

Fig. 4. Vertical profiles of chlorophyll- $a$ (Tchl- $a$ ) made with GF/F filters and $0.2 \mu \mathrm{m}$ Teflon membranes.

the Marquesas area and east of $110^{\circ} \mathrm{W}$, the entire DCM was well below the limit of the photic zone in the SPG. Within this DCM, chlorophyll concentrations were confined to a narrow range ( 0.15 to $\left.0.20 \mu \mathrm{gl}^{-1}\right)$ whatever the depth; and no significant relationship was found between the depth of the DMC and chlorophyll concentration.

Previous work has indicated that GF/F filters are not efficient in collecting all the chlorophyll particles, especially in very oligotrophic waters (Dickson and Wheeler, 1993). This investigation, carried out in one of the most oligotrophic areas of the world, enabled us to test the efficiency of the GF/F filters. Two comparison profiles carried out at the most oligotrophic site $\left(114^{\circ} \mathrm{W}\right.$ and $\left.26^{\circ} \mathrm{S}\right)$ clearly demonstrated that pre-combusted $\mathrm{GF} / \mathrm{F}$ filters were as efficient as the $0.2 \mu \mathrm{m}$ Teflon membranes (Fig. 4) in determining chlorophyll concentrations, even in these very poor oceanic waters dominated by small picophytoplankton (Grob et al., 2007). This observation contradicts Dickson and Wheeler's results and confirms those of Chavez et al. (1995) that GF/F filters are adequate for collecting TChl- $a$ in the open oligotrophic ocean.

Biomass in terms of particulate organic carbon, particulate nitrogen and particulate phosphorus collected on $0.2 \mu \mathrm{m}$ Teflon membranes (Fig. 3) showed very different patterns to those of chlorophyll. The Marquesas waters and upwelling areas were again the richest regions with superficial concentrations of POC, PON and POP higher than 6,1 and $0.05 \mu$ moles $1^{-1}$, respectively. The SPG revealed very low values throughout the water column (POC $<4 \mu$ moles $1^{-1}$, PON $<0.5 \mu$ moles $1^{-1}$, POP $<0.02 \mu$ moles $1^{-1}$ ) with no pronounced subsurface maximum as observed for chlorophyll. The eastern area of the SPG (between $110^{\circ} \mathrm{W}$ and $90^{\circ} \mathrm{W}$ ) was richer than the western area, with POC, PON and POP higher than 5, 0.5 and $0.025 \mu$ moles $1^{-1}$, respectively. Although surface concentrations were higher near the Marquesas Islands and in the upwelling region than in the SPG, the differences were less than twofold, compared with the ten and thousand fold differences found in surface TChl- $a$

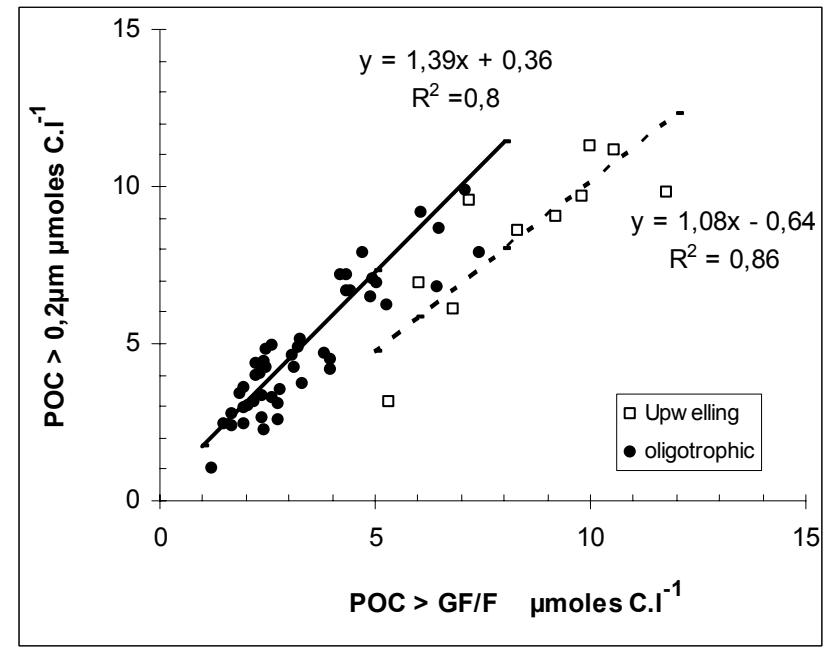

Fig. 5. Comparison between particulate organic carbon measured on $0.2 \mu \mathrm{m}$ Teflon membranes by a wet-oxidation method (POC in $\mu$ moles $1^{-1}$ ) and particulate carbon on GF/F filters measured using High temperature combustion (PC in $\mu$ moles $1^{-1}$ ). Linear relationships are obtained using model II regression.

and nitrate concentrations, respectively. Depth distributions of POC, PON and POP were uniform over the photic zone, lacked pronounced subsurface maxima, but showed a characteristic decrease to the bottom of the euphotic zone. Particulate carbon and particulate nitrogen collected on $\mathrm{GF} / \mathrm{F}$ filters described the same geographical pattern (Fig. 3). Maximum biomass was found in surface upwelling waters and in the Marquesas vicinity while a homogeneous vertical distribution was observed in the SPG.

The estimates of POM in the $>0.2 \mu \mathrm{m}$ size fraction (collected on Teflon filters) and in the $>0.7 \mu \mathrm{m}$ size fraction (approximate GF/F filter pore size) were compared by calculating the geometric mean model II regression, which take into account the measurement errors in both variables. Results obtained from upwelling waters appeared significantly different from other waters (Fig. 5) and were treated separately. On average, $>0.2 \mu \mathrm{m}$ POC and PON were 1.38, 1.24 times higher than the corresponding $0.7 \mu \mathrm{m}$ estimates (Table 2), indicating that a large proportion of POC/PON particles were $<0.7 \mu \mathrm{m}$ and therefore the GF/F filters were shown to be underestimating the values. In some cases, this underestimation reached $50 \%$, i.e. in the SPG. In the case of N-replete water from the upwelling, the linear regression slope was not significantly different from 1 , indicating that there was no significant biomass lower than $0.7 \mu \mathrm{m}$.

When all the data were pooled the relationship between POC versus PON and POC versus POP were close to the Redfield ratio for the $>0.2 \mu \mathrm{m}$ fraction and for the $>0.7 \mu \mathrm{m}$ GF/F filter fraction (Table 2). However, intercepts of the regression equations for the $0.2 \mu \mathrm{m}$ teflon and GF/F filter comparisons showed that particles in the $<0.7 \mu \mathrm{m}$ filtrate 
Table 2. Comparative study of retention efficiency of $0.2 \mu \mathrm{m}$ Teflon membrane and GF/F Whatman ${ }^{\circledR}$ filters (approximate $0.7 \mu \mathrm{m}$ pore size) for collection of particulate carbon (POC and PC), particulate nitrogen (PON), particulate phosphorus (POP) and chlorophyll (Tchl- $a$ ). Coefficient regression and coefficient correlation are obtained from model II regression.

\begin{tabular}{|c|c|c|c|c|c|}
\hline \multicolumn{3}{|c|}{ All BIOSOPE data, except upwelling $\left(141^{\circ}-82^{\circ} \mathrm{W}\right)$} & \multirow[t]{2}{*}{ upwelling $\left(81^{\circ} \mathrm{W}-74^{\circ} \mathrm{W}\right)$} & \multirow[b]{2}{*}{$r^{2}$} & \multirow[b]{2}{*}{$\mathrm{n}$} \\
\hline & $r^{2}$ & $\mathrm{n}$ & & & \\
\hline $\mathrm{POC}_{0.2 \mu \mathrm{m}}=1.38 \mathrm{PC}_{0.7 \mu m}+0.36$ & 0.80 & 52 & $\mathrm{POC}_{0.2 \mu \mathrm{m}}=1.08 \mathrm{PC}_{0.7 \mu m}-0.6$ & 0.85 & 10 \\
\hline $\mathrm{PON}_{0.2 \mu \mathrm{m}}=1.24 \mathrm{PON}_{0.7 \mu \mathrm{m}}+0.04$ & 0.75 & 52 & $\mathrm{PON}_{0.2 \mu m}=1.08 \mathrm{PON}_{0.7 \mu m}-0.36$ & 0.98 & 10 \\
\hline $\mathrm{POC}_{0.2 \mu \mathrm{m}}=6.19 \mathrm{PON}_{0.2 \mu \mathrm{m}}+0.94$ & 0.66 & 133 & $\mathrm{POC}_{0.2 \mu \mathrm{m}}=5.9 \mathrm{PON}_{0.2 \mu \mathrm{m}}+0.10$ & 0.90 & 27 \\
\hline $\mathrm{POC}_{0.2 \mu \mathrm{m}}=103 \mathrm{POP}_{0.2 \mu \mathrm{m}}+1.5$ & 0.629 & 133 & $\mathrm{POC}_{0.2 \mu m}=74 \mathrm{POP}_{0.2 \mu m}+0.66$ & 0.85 & 27 \\
\hline $\mathrm{POC}_{0.2 \mu m}=15.3$ Tchl $-a+1.6$ & 0.40 & 93 & $\mathrm{POC}_{0.2 \mu m}=4.9$ Tchl $-a+3.8$ & 0.39 & 18 \\
\hline $\mathrm{PON}_{0.2 \mu m}=2.6$ Tchl $-a+0.1$ & 0.60 & 92 & $\mathrm{PON}_{0.2 \mu m}=0.9$ Tchl $-a+0.58$ & 0.36 & 18 \\
\hline $\mathrm{POP}_{0.2 \mu m}=0.14 \mathrm{Tchl}-a-0.00$ & 0.48 & 92 & $\mathrm{POP}_{0.2 \mu m}=0.07$ Tchl $-a+0.038$ & 0.2 & 18 \\
\hline $\mathrm{PC}_{0.7 \mu m}=6.4 \mathrm{PON}_{0.7 \mu m}+0.17$ & 0.87 & 207 & $\mathrm{PC}_{0.7 \mu m}=6.3 \mathrm{PON}_{0.7 \mu m}-1.74$ & 0.88 & 29 \\
\hline $\mathrm{PC}_{0.7 \mu m}=17.0$ Tchl $-a+0.71$ & 0.31 & 207 & $\mathrm{PC}_{0.7 \mu m}=7.9$ Tchl- $a+2.85$ & 0.72 & 29 \\
\hline $\mathrm{PON}_{0.7 \mu m}=2.66$ Tchl $-a+0.084$ & 0.44 & 207 & $\mathrm{PON}_{0.7 \mu m}=1.25$ Tchl $-a+0.73$ & 0.75 & 29 \\
\hline Tchl $-a_{0.2 \mu m}=0.98$ Tchl $-a_{0.7 \mu m}+0.001$ & 0.99 & 23 & & & \\
\hline
\end{tabular}
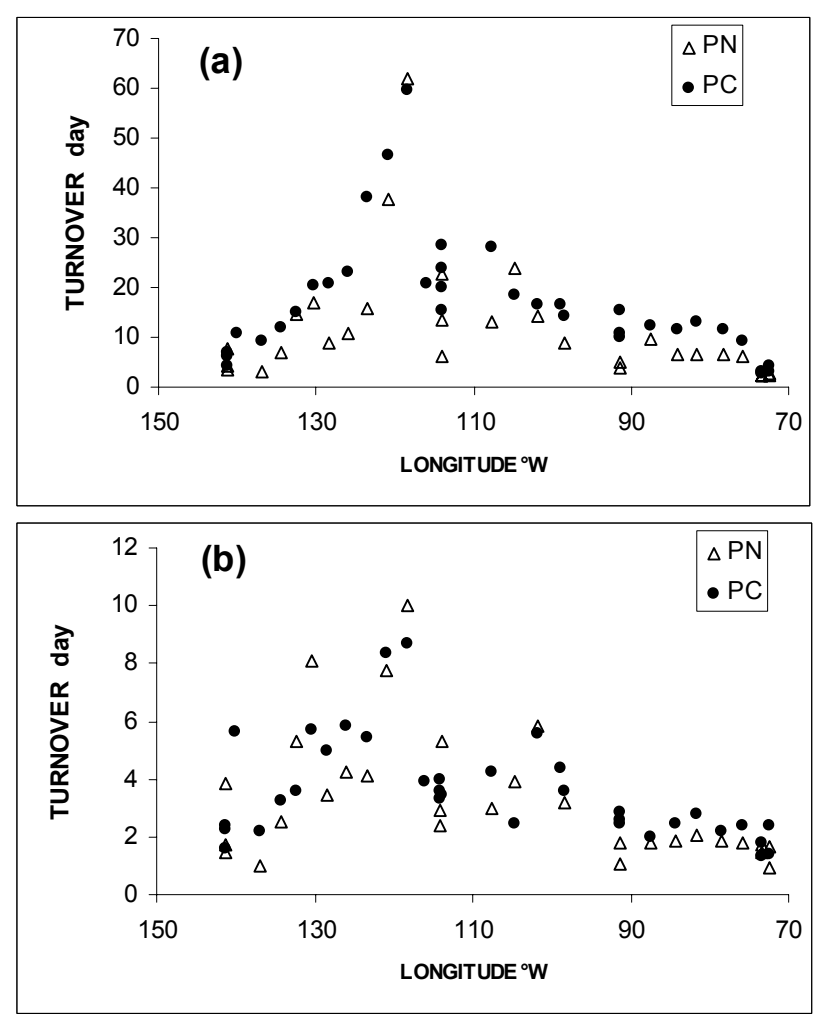

Fig. 6. Longitudinal evolution of turnover time (day) of particulate carbon (PC) and particulate nitrogen (PN) collected on GF/F filters, estimated as the $\mathrm{PC} /$ versus photosynthesis and $\mathrm{PN} /$ nitrogen uptake rates ratios. (a) total material collected on GF/F filters. (b) particles containing chlorophyll estimated from Tchl- $a$ Vs PC and TChl- $a$ vs PN relationship (see Table 2).

have a $\mathrm{C} / \mathrm{N}$ ratio slightly higher than the Redfield value $(0.36 / 0.04=9)$. Consequently, the particulate matter in the

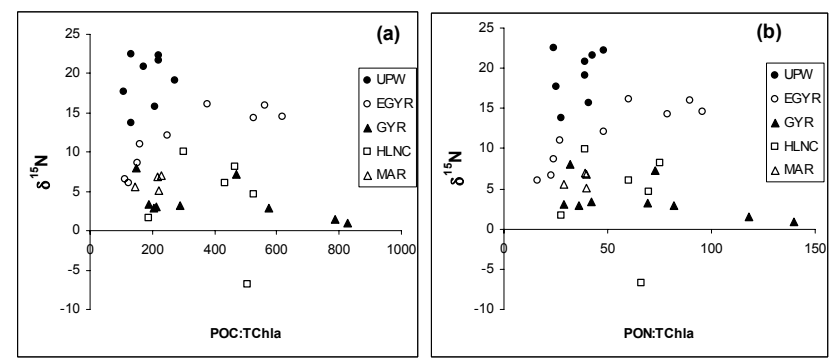

Fig. 7. Relationship between $\delta^{15} \mathrm{~N}$ PON (\%o) with the ratio of POC:TChl (a) and PON:Tchl (b). There is no significant relationship between $\delta^{15} \mathrm{~N}$ PON and the ratios, except for the east Gyre area (EGY) where $\delta^{15} \mathrm{~N}$ PON $=0.016$ POC:TChl +6.5 with $r^{2}=0.73$ and $\delta^{15} \mathrm{~N}$ PON=0.11 PON: Tchl +6.1 with $r^{2}=0.76$.

$<$ GF/F filtrate was essentially carbon rich with no chlorophyll particles. Using photosynthesis rates and nitrogen uptake (Raimbault and Garcia, 2007), we can calculate the residence time of $\mathrm{PC}$ and $\mathrm{PN}$ collected on $\mathrm{GF} / \mathrm{F}$ filters in the photic zone (Fig. 6a) as proposed by Copin-Montégut and Copin-Montégut (1978). Average residence times of less than 10 days were found in the Marquesas Island waters and around 4-5 days in the upwelling, while values increased to more than 30 days in the SPG. It should be noted that carbon turnover times were 10 to $15 \%$ higher than those of nitrogen. Using POM vs TChl- $a$ relationships (Table 2), the turnover time of photosynthetic particles, containing chlorophyll, can be estimated (Fig. 6b). In this case, residence times were close to 1 day in the upwelling, 2 to 3 days in the Marquesas sector and ranged from 4 to 6 days in the SPG.

The distribution of the natural ${ }^{15} \mathrm{~N}$ isotope $\left(\delta^{15} \mathrm{~N}\right)$ can provide useful information regarding the origin of this organic matter. The abundance of this stable isotope of nitrogen $\left({ }^{15} \mathrm{~N}\right)$ has been widely employed for $\mathrm{N}$ cycle studies in 


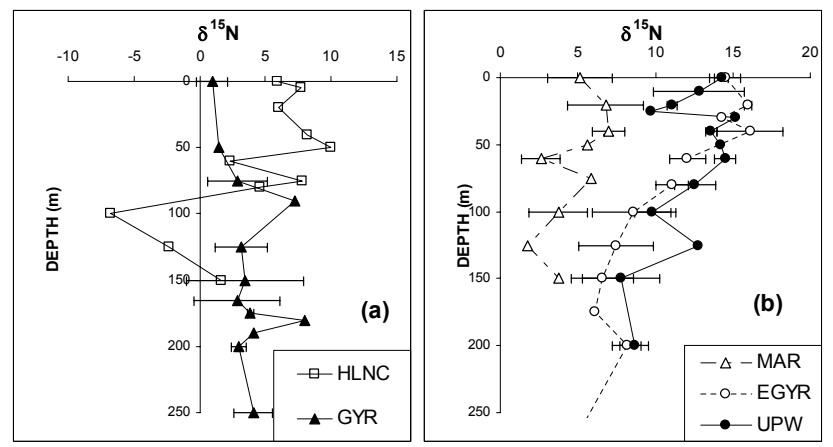

Fig. 8. Vertical profiles of ${ }^{15} \mathrm{~N}$ natural abundance $\left(\delta^{15} \mathrm{~N}\right)$ in suspended particulate matter within the euphotic zone obtained at 5 sites in the South East Pacific. (MAR $=141.3^{\circ} \mathrm{W} ; 8.4^{\circ} \mathrm{S}$; $\mathrm{HLNC}=136.8^{\circ} \mathrm{W} ; 9^{\circ} \mathrm{S}$; GYR $\left.=114^{\circ} \mathrm{W}, 26^{\circ} \mathrm{S}\right)$; EGY=eastern border of the gyre $\left(91.4^{\circ} \mathrm{W}, 31.8^{\circ} \mathrm{S} ; \mathrm{UPW}=73^{\circ} \mathrm{W}-34^{\circ} \mathrm{S}\right)$.

the oceans (e.g. Wada and Hattori, 1991), as differences in the natural abundance ${ }^{15} \mathrm{~N}:{ }^{14} \mathrm{~N}$ ratio $(0.3663 \%)$ between organic matter pools can be used to constrain the source materials from which they were derived, but only in absence of trophic bias. It is well known that inclusion of particulate matter derived from higher trophic levels than phytoplankton, i.e. zooplankton, would add PON enriched in ${ }^{15} \mathrm{~N}$ (Minagawa and Wada, 1984) and not chlorophyll to the particulate biomass. Thus, as proposed by Waser et al. (2000) and Mahaffey et al. (2004), this trophic bias appears important if a positive relationship between the ratio of POC:Chlorophyll or PON:chlorophyll and $\delta^{15} \mathrm{~N}$ is observed. Figures $7 \mathrm{a}$ and $7 \mathrm{~b}$ revealed that there was no such relationship in the regions investigated, except for samples from east Gyre (EGY). Consequently, suspended PON in the latest region was assumed to reflect some influence of trophic transfer and can not be presented as the composition of phytoplankton. For the other regions, the range of $\delta^{15} \mathrm{~N}$ in the suspended particulate matter collected on GF/F filters varied greatly in the superficial layer but seemed to display coherent patterns with the trophic gradient (Fig. 8). The western area of the transect (MAR and HNLC sites) showed typical values of 5-6\%o for marine phytoplankton found in oceanic regions that are not strongly affected by upwelling or derived $\mathrm{N}$-inputs (Altabet and McCarthy, 1986). This value was close to those of $\delta^{15} \mathrm{~N}-\mathrm{NO}_{3}(6.5 \%$ ) reported in the central Pacific (Liu and Kaplan, 1989). Large negative values were found in deep waters around $\left(140^{\circ} \mathrm{W}\right)$ associated with high nitrite and ammonium concentrations (Fig. 2). This could be due to biological utilization of regenerated nitrogen generally characterized by negative isotope fractionation (Hoch et al., 1992), since ammonium excreted by zooplankton is depleted in ${ }^{15} \mathrm{~N}$ (Checkley and Miller, 1989). The Central South Pacific Gyre was characterized by low $\delta^{15} \mathrm{~N}$, close to $2 \%$, which is the signature of enhanced dinitrogen fixation (Minagawa and Wada, 1984; Dore et al., 2002). The highest $\delta^{15} \mathrm{~N}$ values (up to
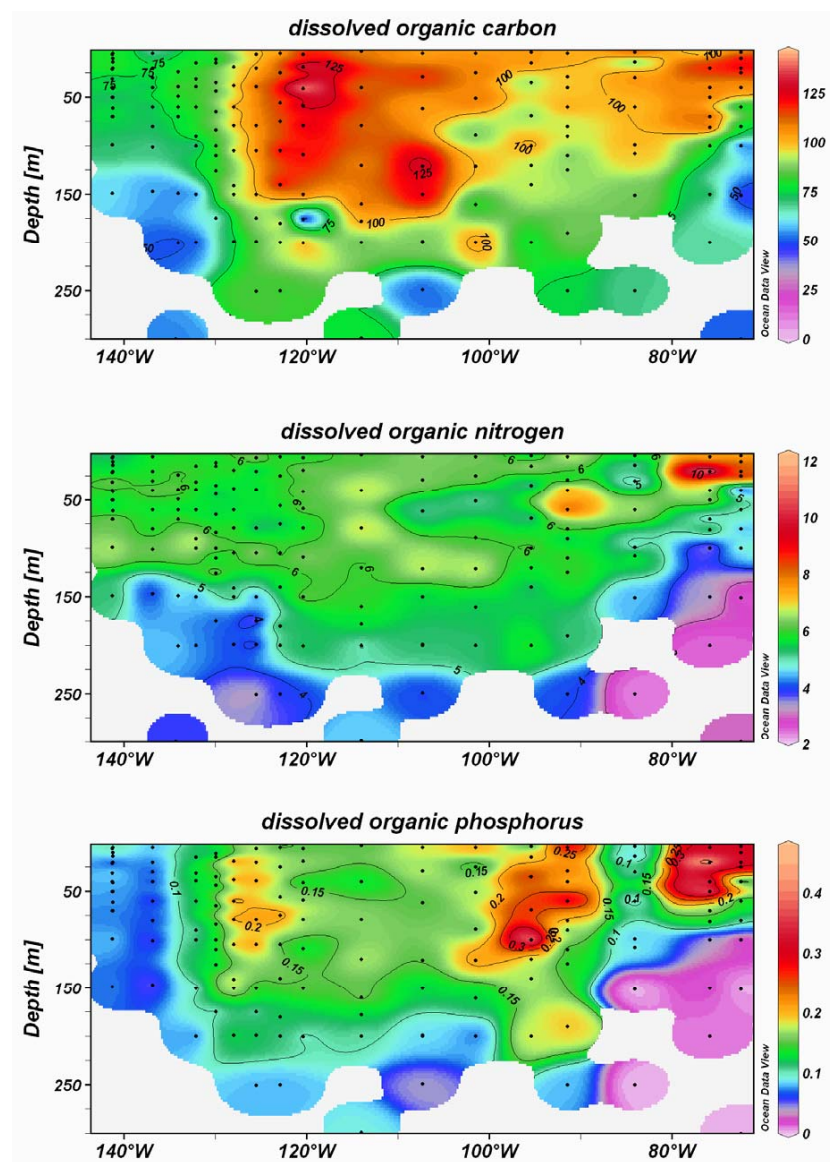

Fig. 9. Vertical section of dissolved organic carbon (DOC), dissolved organic nitrogen (DON) and dissolved organic phosphorus (DOP). Units are $\mu$ moles $1^{-1}$ (Ocean Data View software (ODV), version 3.1, Reiner Schlitzer, http://odv.awi.de).

$15 \%$ ) were found in the upwelling area. These values overlap those generally observed in oceanic waters, indicating the use of a nitrogen source enriched in ${ }^{15} \mathrm{~N}$. In fact, it is well known that $\delta^{15} \mathrm{~N}$ in the nitrate pool increases as concentrations decrease, because of the rapid utilization of the light isotope ${ }^{14} \mathrm{~N}$, which is preferentially assimilated during photosynthesis. Consumption of nitrate during the early stages of the upwelling, when diatoms grow actively, will be accompanied by a significant isotopic fractionation leading to a large increase in $\delta^{15} \mathrm{~N}$ (up to $30 \%$ ), when residual nitrate reaches 10 to $20 \%$ of the initial concentration (Montoya and Mc Carthy, 1995). Phytoplankton using this residual ${ }^{15} \mathrm{~N}-$ enriched nitrate for growth, as occurred in offshore upwelling water sampled during this study, could exhibit a heavier nitrogen signature. Another explanation could be the biological use of enriched ${ }^{15} \mathrm{~N}$-nitrate coming from the denitrification layer, as $\delta^{15} \mathrm{~N}$ in the nitrate pool can reach $20 \%$ o during this process (Cline and Kaplan, 1975). 


\subsection{Distribution of dissolved organic nutrients}

The vertical profiles of dissolved organic carbon (DOC), dissolved organic nitrogen (DON) and dissolved organic phosphorus (POD) are shown in Fig. 9. The main feature was the high DOC concentration $\left(>100 \mu\right.$ moles..$^{-1}$ ) exhibiting a patchy maximum in the superficial layer $(0$ $150 \mathrm{~m}$ ) in the SPG (between $125^{\circ} \mathrm{W}$ and $100^{\circ} \mathrm{W}$ ). This DOC concentration was slightly higher than those measured in the surface waters of the upwelling $\left(100 \mu\right.$ moles. $\left.l^{-1}\right)$. The lowest surface concentrations $\left(<80 \mu\right.$ moles $\left.^{-1}\right)$ were found in the Marquesas area. Classical low DOC values $\left(<60 \mu\right.$ moles $\left.^{-1}\right)$ were measured at depths below $70 \mathrm{~m}$ in the Marquesas and upwelling regions, and only below 250 $300 \mathrm{~m}$ in the central region. The DOC concentrations in deeper waters $(>500 \mathrm{~m})$ presented no significant variations ( $47 \pm 5 \mu$ moles $^{-1}$ ) and were consistent with values found in various oceanic regions (Hansell and Carlson, 1998). The lowest value $\left(42.7 \mu\right.$ moles $\left.1^{-1}\right)$ was measured at $3000 \mathrm{~m}$ $\left(114^{\circ} \mathrm{W}-26^{\circ} \mathrm{S}\right)$. DON concentrations were uniformly distributed in the photic layer and no subsurface maximum was observed. The general pattern of DON showed no significant geographical variation, with concentrations ranging from 5.5 to $6 \mu$ moles $1^{-1}$ throughout the $0-150 \mathrm{~m}$ water column, with the exception of the upwelling where concentrations reached $9 \mu$ moles $\mathrm{N}^{-1}$ near the surface. Classical low residual concentrations $\left(<3 \mu\right.$ moles $\left.^{-1}\right)$ were measured below $250 \mathrm{~m}$. The lowest value $\left(2.7-3 \mu\right.$ moles $\left.1^{-1}\right)$ was measured below $1200 \mathrm{~m}$. DOP exhibited a more variable distribution with two marked maxima at the eastern edge of the SPG and in the upwelling $\left(>0.2 \mu\right.$ moles $\left.1^{-1}\right)$. Elsewhere, superficial values ranged between 0.10 and $0.15 \mu$ moles $1^{-1}$. The isoline $0.1 \mu$ moles $~^{-1}$ was generally located around $20 \mathrm{~m}$ with the exception of the upwelling region where it reached $100 \mathrm{~m}$. DOP decreased rapidly below $250 \mathrm{~m}$ becoming abruptly, undetectable. Contrary to carbon and nitrogen, phosphorus is more quickly liberated from dead material (Menzel and Ryther, 1964; Clark et al., 1999). As a consequence, in the open ocean, the proportion of detrital $\mathrm{P}$ in the phosphorus pool is low (Faul et al., 2005), and no DOP was detected in the deep waters. Due to total inorganic nitrogen depletion DON accounted for almost $100 \%$ of the nitrogen in the surface water of the SPG, while DOP accounted for 20 to $50 \%$ of total phosphorus.

Another view of the geographical distribution of the major biogeochemical parameters can be demonstrated using the pattern of integrated values over the euphotic zone (Ze). The distribution of integrated nitrate (Fig. 10) confirms the main characteristic of the SPG, i.e. complete depletion of inorganic nitrogen. Integration over $\mathrm{Ze}$ was close to zero between 130 and $100^{\circ} \mathrm{W}$. Integrated chlorophyll followed the same geographical trend, with very low values in the SPG, where Ze integration was lower than $10 \mathrm{mg} \mathrm{m}^{-2}$. It should be noted that a large proportion of chlorophyll (up to $50 \%$ ) was located below the $1 \%$ light penetration depth, with the exception of the upwelling and Marquesas regions. Consequently, in the SPG, integrated Tchl- $a$ over $1.5 \mathrm{Ze}$ was twofold higher than content over Ze. In contrast to nitrate and chlorophyll, integrated particulate organic matter (in terms of POC, PON and POP) did not show a clear geographical gradient. Integrated values over Ze, remained more or less constant along the transect, except in the upwelling system, where values significantly increased. The ranges were 400 $500,50-75$ and $2-4$ mmoles $^{-2}$ for POC, PON and POP, respectively. In the upwelling, content increased significantly reaching 900, 180 and $10 \mathrm{mmoles}^{-2}$ for POC, PON and POP, respectively.

In contrast, integrated dissolved organic carbon $(\Sigma D O C)$, dissolved organic nitrogen, $(\Sigma D O N)$ and dissolved organic phosphate $(\Sigma D O P)$, exhibited lowest values in the upwelling and Marquesas regions $\left(5000,500\right.$ and $15 \mathrm{mmoles} \mathrm{m}^{-2}$, for $\Sigma D O C, \Sigma D O N$ and $\Sigma$ DOP over the photic zone, respectively). The highest values were measured in the centre of the gyre between 115 and $105^{\circ} \mathrm{W}$, where $\Sigma D O C, \Sigma D O N$ and $\Sigma$ DOP reached 17000,900 and 30 mmoles $^{-2}$, respectively. Over the photic layer, the integrated inorganic and organic dissolved nutrient data exhibited a clearly opposing trend in the South Pacific

\section{Discussion}

The BIOSOPE transect crossed the central region of the South Pacific, while extreme stations were influenced either by the Marquesas Islands or Chilean upwelling. As initially expected and confirmed by satellite imagery, the Central South Pacific Gyre is a very oligotrophic area (Claustre and Maritorena, 2003), characterized by a strong depletion in inorganic nitrogen and very low phytoplanktonic biomass. Since the development of sensitive analytical procedures, it has been shown that nitrate concentrations of subtropical surface waters over much of the world's oceans, including the subtropical gyres, is often at sub-micromolar concentrations ( 3 to $<50$ nmoles $1^{-1}$ ). Using a chemiluminescent method, Garside (1985) and Eppley et al. (1990) previously found nitrate concentrations $<10 \mathrm{nM}$ in the Sargasso Sea and in the subtropical Pacific. These concentrations, which would be depleted in a few hours by the ambient assemblages of phytoplankton, were low but not zero. For these authors, these residual concentrations were kept greater than zero due to some physical process such as atmospheric inputs and nighttime convection. We could assume that all of these processes occur at very low rates in the South Pacific Gyre (SPG) leading to a permanent and complete nitrate depletion (nitrate content over the photic layer was close to $0 \mu$ moles $\mathrm{m}^{-2}$ ). More, top-down wind-driven mixing of the water column seldom deepens the mixed layer below $100 \mathrm{~m}$, and measurable increases of nitrate concentration in surface waters were unlikely over the year in the SPG, as the nitracline was below $160 \mathrm{~m}$. 

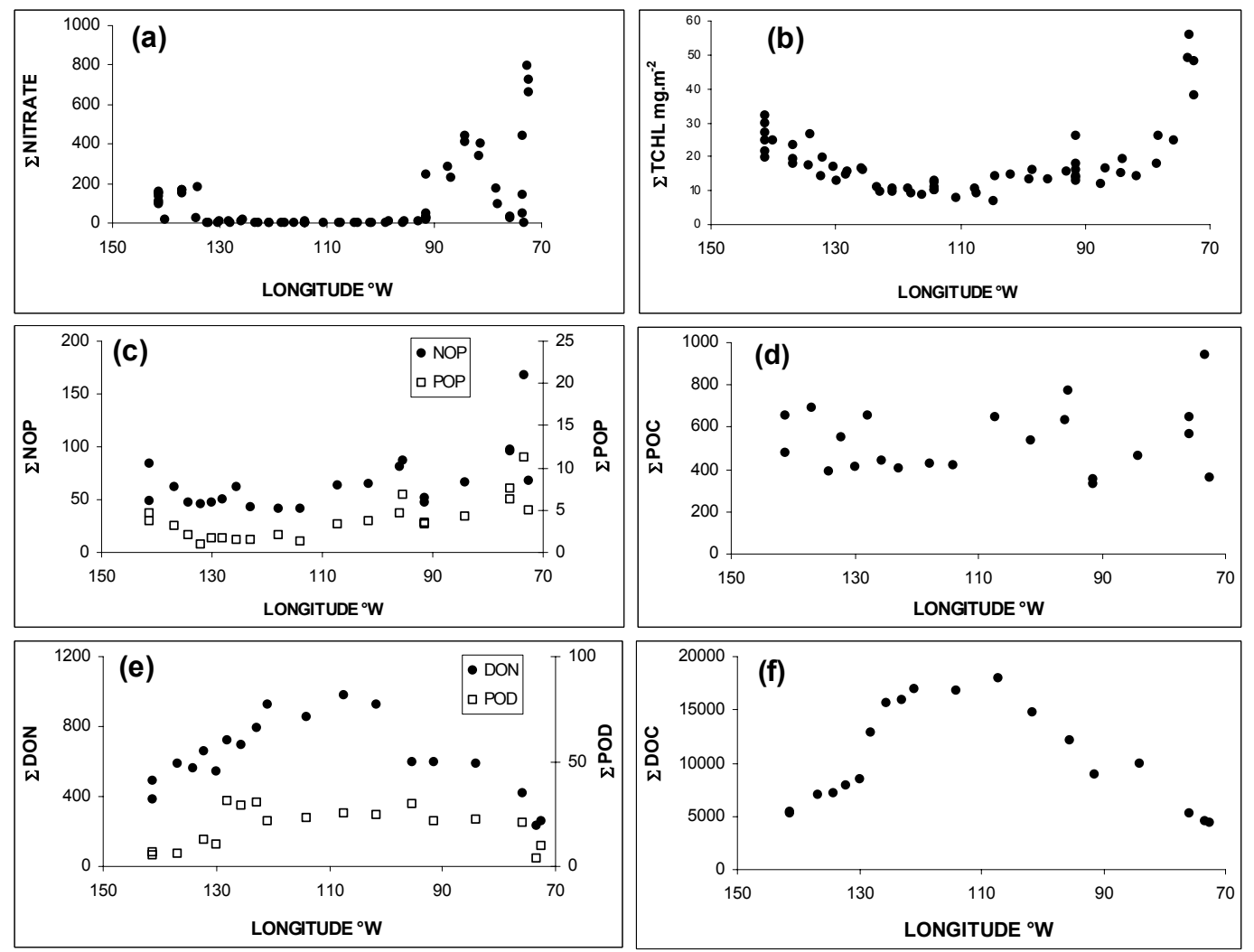

Fig. 10. Geographical distribution of nitrate ( $\Sigma$ nitrate), total chlorophyll- $a$ ( $\Sigma$ TCHL), dissolved organic carbon $(\Sigma D O C)$, dissolved organic nitrogen $(\Sigma \mathrm{DON})$, dissolved organic phosphorus $(\Sigma \mathrm{DOP})$, particulate organic carbon $(\Sigma \mathrm{POC})$, particulate organic nitrogen $(\Sigma \mathrm{PON})$ and particulate organic phosphorus $(\Sigma \mathrm{POP})$ integrated over the photic zone (Ze=1\% surface light).

Similarly, the very low concentrations of nitrite and ammonium and the lack of a significant subsurface maximum, generally found in all stratified systems, were unexpected. It has been hypothesized that subsurface ammonium maxima are produced by local imbalances between ammonium regeneration and uptake, caused by active regeneration at the base of the photic zone where ammonium uptake by the phytoplankton is inhibited by low light intensities. In the present case, ammonium concentrations below the detection limit could be due to the lack of regeneration activity, or to a tight coupling between regeneration and ammonium uptake and ammonium oxidation (=nitrification). Brandhorst (1958) and Wada and Hattori (1971) suggested that nitrite originates from bacterial oxidation of ammonia. Vaccaro and Ryther (1960) first proposed that the appearance of nitrite near the nitracline would be caused by the reduction of nitrate by phytoplankton. Reasoning from laboratory experiments (Raimbault, 1986), argued that increases in nitrite concentrations are expected when phytoplankton starved of nitrogen, are exposed to increased concentrations of nitrate and decreased temperature and irradiances, such as those occurring at the base of the photic layer. The primary nitrite maximum generally occurs in a light limited regime where nitrate is abundant and can define precisely the deep layer of the euphotic zone in which light becomes a limiting factor on primary production (Voituriez and Herbland, 1977). Thus, the primary nitrite maximum widely distributed in the ocean (Vaccaro and Ryther, 1960; Olson, 1981) has often been considered as an indicator of new production through phytoplankton excretion, or bacterial oxidation of organic matter, as well as a signature of the depth at which light limitation occurs (Ward et al., 1989). In a recent review, Lomas and Lipschultz (2006) concluded for the predominance of excretion from phytoplankton growing on nitrate, while bacterial nitrification likely playing only a supporting role. In return, the very low concentration of nitrite as observed at the base of the photic layer in the SPG, could reveal a very low diffusion of nitrate, as well as the lack of significant new production (nitrate uptake by phytoplankton) both in the DCM and in the nitracline.

In spite of the marked depletion in inorganic nitrogen leading to undetectable concentrations throughout the $0-160 \mathrm{~m}$ water column, phosphate concentrations, while being lower than those found near to the Marquesas Islands and Chilean coast, remained $>0.1 \mu$ moles $1^{-1}$ in the SPG. The significant amounts of phosphate in the superficial nitrate-depleted 


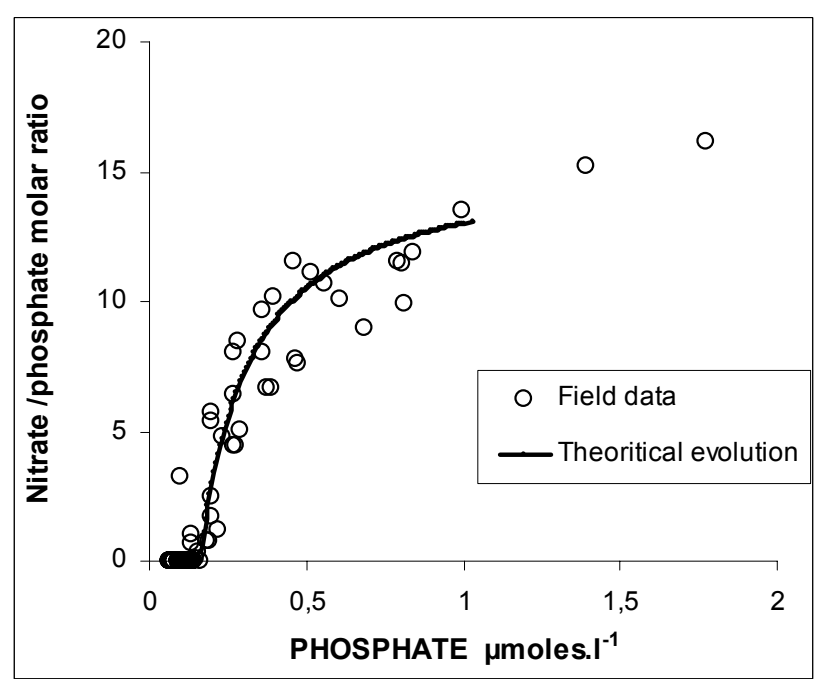

Fig. 11. Nitrate/phosphate ratio versus phosphate concentration in the SPG; Open circles=field data. The curve fit the theoretical relationship obtained from phosphate and nitrate utilization by phytoplankton, according to the Redfield ratio (15.5), of deep nutrients coming from below the photic zone with a nitrate:phosphate ratio $\approx 12-13$.

layer of this tropical region confirmed previous observations made at $150^{\circ} \mathrm{W}$ and $16^{\circ} \mathrm{S}$ (Raimbault et al., 1999c). The reason for this excess phosphate and/ or the deficit in nitrate (around $2 \mu$ moles $1^{-1}$ when applying the N/P Redfield ratio) is not clear. But it reflects the general feature of nitrate and phosphate distribution in the world ocean, where nutrientdepleted waters usually contain a small residue of phosphate (Tyrell, 1999). This has led to the biological concept that dissolved inorganic nitrogen (mainly nitrate) is the most limiting nutrient and that nitrogen dynamics are important for controlling phytoplankton productivity. However, the geochemists point of view would suggest that phosphate could be the ultimate limiting factor in aquatic systems, because of the nitrogen-fixers, which can use the available atmospheric dinitrogen. This scheme has been experimentally demonstrated in lakes, but not in the ocean (Smith, 1983). In return, according to this hypothesis, the residual phosphate found in the South east Pacific could demonstrate very low fixation of nitrogen, although available inorganic phosphorus offers favorable conditions for nitrogen-fixers. In fact low $\delta^{15} \mathrm{~N}$ in $\mathrm{POM}$ confirms that nitrogen fixation is an important process in the SPG, but the rates are too low to drive phosphate depletion (Raimbault and Garcia, 2007), at least during the season investigated here. It should be noted that nitrate/phosphate ratios were less than the Redfield's constant of 16 (Redfield et al., 1963) down to $400-500 \mathrm{~m}$, indicating that the deep reservoir of nutrients was also nitrogen deficient. The eastern Pacific Ocean near the Chilean coast is one of the major areas of denitrification in the world oceans (Codispoti et al., 1976). Deutsch et al. (2001) argue that denitrification inside the oxygen minimum zone of the Peru-Chilean upwelling generates nitrogen-deficient waters which carry surplus phosphorus. Due to the isolation of the SPG, nutrient input into the euphotic zone appears to be mainly through diffusive process, which in this case could bring in nitrate and phosphate with a low N/P ratio (around 12-13). This observation suggests that the biological utilization of deep nutrients by phytoplankton with a typical N/P requirement of 15.5 would decrease the N/P ratios to very low values. Our field data closely fit such a theoretical removal of nutrients (Fig. 11), suggesting that phytoplankton consumption of Ndeficient nutrient pools would be the probable cause of such a phosphate residual value $\left(\approx 0.1 \mu\right.$ moles $\left.1^{-1}\right)$ in the photic layer.

The nitrate/silicic acid ratio $\left(\mathrm{NO}_{3} / \mathrm{Si}\right)$ generally ranged between 1 and 4 over the whole transect except in the SPG, where nitrate depletion gave a ratio close to $0 . \mathrm{A}$ high $\mathrm{NO}_{3} / \mathrm{Si}$ ratio ( $>5$ and up to 8 ) was observed in the low salinity tongue located at $95^{\circ} \mathrm{W}$. In comparison to the Redfield ratio and to the phytoplankton requirement (Fleming, 1940), these values indicate a deficit in silicic acid relative to nitrate (when detectable) in the 0-300 m superficial layer, especially in the euphotic zone. A strong deficit in silicic acid was noticeable in the western area near the upwelling zone. According to the elemental composition of diatoms, characterized by the $\mathrm{N} / \mathrm{Si}$ ratio of 1 (Brzezinski, 1985), it is expected that diatoms will take up nutrients from surrounding waters with a similar ratio. Thus, values of $\mathrm{NO}_{3} / \mathrm{Si}$ ratio higher than 1 may imply silicate-limitation.

Changes in the values and shapes of the chlorophyll profiles from west to east clearly show the expected differences in productivity driven by nutrient availability. The hyper oligotrophic centre of the SPG make up the clearest water of the worlds ocean (Morel et al., 2007) and is characterized by extremely low surface Tchl- $a$ concentrations $\left(<0.03 \mu \mathrm{gl}^{-1}\right)$. In this region, primary production was strongly nutrient limited considering the absence of terrestrial inputs (Jickells et al., 2005) and the depth of the nitracline (around 160-180 m). Nevertheless, the decrease in chlorophyll content between the upwelling and SPG was much lower (about four-fold) than the decrease in nitrate content (hundred to thousand fold). A chlorophyll maximum, permanently associated with the nitracline, was always detectable with values never lower than $0.20 \mu \mathrm{gl}^{-1}$, at least ten-fold greater than measured in the upper layer. When the data was pooled no correlation was found between the magnitude of the DCM and nutrient concentration. Vertical distribution of POM was nearly always homogeneous without a subsurface maximum layer. With exception of the upwelling waters, the chlorophyll maximum was never associated with an increase of biomass in terms of carbon, nitrogen or phosphorus. Moreover, while surface concentrations reflected the oligotrophic conditions with lowest values in the SPG (by a factor 2), the integrated values over the photic zone did not reveal such marked trophic gradients. In fact, the photic layer of the SPG contains slightly 

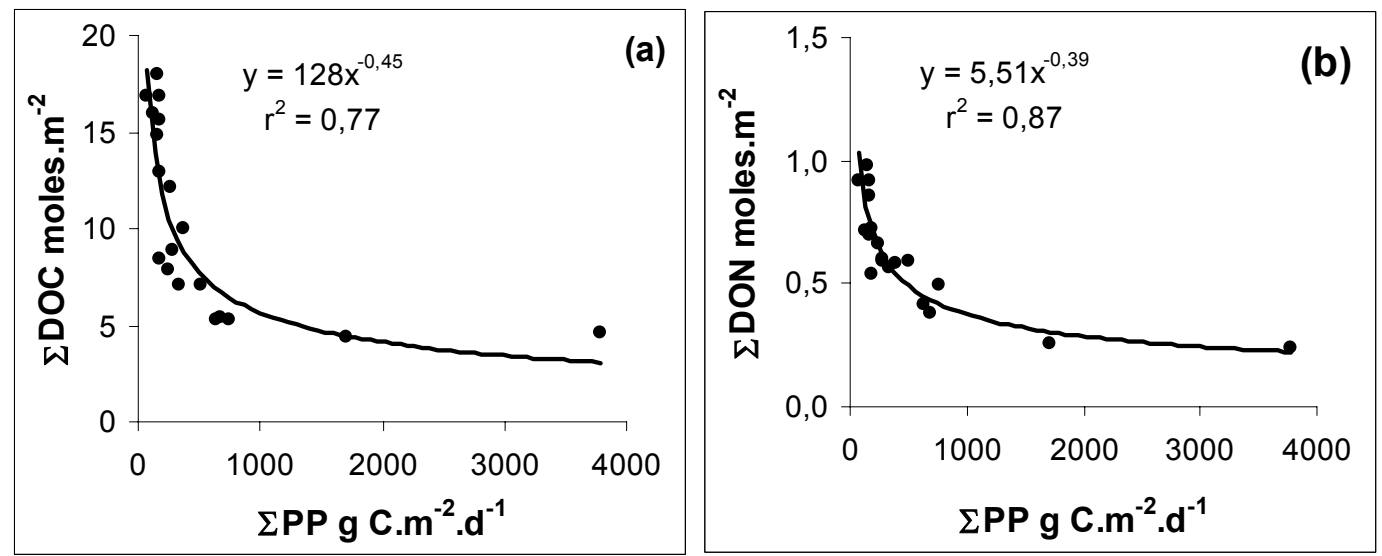

Fig. 12. Contents of dissolved organic carbon ((a): $\Sigma$ DOC) and dissolved organic nitrogen ((b): $\Sigma$ DON) over the photic layer versus integrated primary production $(\Sigma \mathrm{PP})$.

less POM than the upwelling, but as much as the Marquesas areas. However, all of these oceanic regions were characterized by very different turnover times for particulate matter, as well as by different nitrogen sources as indicated by the natural abundance of $\delta^{\mathrm{x} 5} \mathrm{~N}$. The SPG was characterized by particulate matter having very long residence times (20 days). However, values found in the upwelling and the Marquesas region (5 to 10 days) were close to those noted in the Central north Pacific (Laws et al., 1987) and in the equatorial Pacific (Eppley et al., 1992). The low $\delta^{5} \mathrm{~N}$ of PON (2\%o) suggests a greater role of $\mathrm{N}_{2}$ fixation in supporting production in the SPG, as typically observed in subtropical oceans (Minagawa and Wada, 1986), whereas a higher ratio (5-6\%o) indicated a greater role of nitrate in the surrounding regions. Because $\delta^{5} \mathrm{~N}$ remained very low throughout the photic layer in the SPG, it is clear that (1) vertical mixing does not penetrate the nitracline, and (2) primary production in the superficial layer would be essentially supported by nitrogen regeneration and by $\mathrm{N}_{2}$-fixation (Raimbault and Garcia, 2007), both processes lower $\delta^{\mathrm{x} 5} \mathrm{~N}$ values.

With the exception of the upwelling, POC and PON collected on $0.2 \mu \mathrm{m}$ membranes were higher than those retained on GF/F filters, confirming that the use of GF/F filters can greatly underestimate the concentration of particulate matter, especially in oceanic oligotrophic waters where the underestimation can be up to 50\% (Altabet, 1990; Libby and Wheeler, 1997; Raimbault et al., 2000; Fernandez and Raimbault, 2007). However, the GF/F filters were proven to be efficient in collecting chlorophyll, so we can postulate that the organic matter in the $<0.7 \mu \mathrm{m} \mathrm{GF} / \mathrm{F}$ filtrate was essentially made up of carbon- rich particles ( $\mathrm{POC} / \mathrm{PON}>6.6)$, but without chlorophyll.

The final unexpected result was the large dissolved organic matter (DOM) accumulation in the surface waters of the vast central region of the SPG. DON and DOP concentrations were similar to those generally observed in oceanic waters of the Pacific Ocean (Karl et al., 1993; Raimbault et al., 1999) in spite of very low concentrations of inorganic nutrients. In contrast, our range of DOC found in the SPG ( $>100 \mu$ moles $^{-1}$ ) overlapped concentrations generally observed in surface oceanic waters and were about 10 to $20 \%$ higher than maximal values reported for the North Pacific Gyre (Church et al., 2002). Nevertheless, levels greater than $100 \mu$ moles $^{-1}$ (up to $140 \mu$ moles $1^{-1}$ ) have been previously reported in the North Atlantic (Kepkay and Wells, 1992), although in this case, high DOC concentrations were associated with very high chlorophyll concentrations $\left(>10 \mu \mathrm{gl}^{-1}\right)$. The marked geographical gradient suggests a net in situ source exists, mainly attributed to biological processes since this DOC accumulation was close to the surface layer where elevated primary production was observed (Raimbault and Garcia, 2007). This excess, much higher than the total particulate organic content, was greatest at the western edge of the SPG, associated with a high turnover rate of POM. The C:N ratio of the particles varied little along the transect, ranging from 5 to 7 . In contrast, the global relationship between DOC and DON was significantly higher (DOC $=10.14$ $\left.\mathrm{DON}+0.31 ; r^{2}=0.35 ; n=250\right)$. Excluding old recalcitrant DOM (43 $\mu$ moles. $1^{-1}$ DOC, and $3 \mu$ moles $1^{-1}$ DON), the $\mathrm{C} / \mathrm{N}$ ratio of the "freshly formed DOM" (excess DOM in surface water relative to deep water) was around 16-23, which is close to the range (20-23) found in the North Pacific by Kähler and Koeve (2001) and Karl and Tien (1997). In short, DOM with a C: $\mathrm{N}$ ratio far greater than Redfield's value (low$\mathrm{N}$ DOM or C-rich DOM) was accumulated in the surface water with a magnitude that increased exponentially with levels of oligotrophy as noted here by the rates of primary production (Fig. 12).

It has been assumed that the bulk of DOC (as well as DON and DOP) has its fundamental origin in surface ocean waters via such processes as phytoplankton excretion, lysis or solubility of living and detrital POM, and sloppy feeding 
Table 3. Comparison of gradient and turbulent diffusion of nutrients through the thermocline, calculated from vertical diffusion coefficients $\left(K z=0.76 \pm 0.81 \mathrm{~m}^{2} \mathrm{~d}^{-1}\right)$ and gradients of organic (dissolved organic carbon=DOC, dissolved organic nitrogen $=\mathrm{DON}$ and dissolved organic phosphorus=DOP) or inorganic nutrients (nitrate, phosphate) in the SPG $\left(122^{\circ} \mathrm{W}-101^{\circ} \mathrm{W}\right)$. Upward fluxes are considered as positive and downward fluxes as negative.

\begin{tabular}{lll}
\hline & $\begin{array}{l}\text { Gradient } \\
\mu \text { moles } \mathrm{m}^{-4}\end{array}$ & $\begin{array}{l}\text { Diffusive fluxes } \\
\mu \text { moles } \mathrm{m}^{-2} \mathrm{~d}^{-1}\end{array}$ \\
\hline Nitrate & $75 \pm 22$ & $+57.4 \pm 10$ \\
Phosphate & $5.9 \pm 2$ & $+4.5 \pm 1.1$ \\
DOC & 176 & -134 \\
DON & 6.6 & -5 \\
DOP & 0.4 & -0.3 \\
\hline
\end{tabular}

at various trophic levels. Therefore this DOC concentration is the result of a large array of production, consumption and transformation processes due to biological activity (Williams, 1975). Phytoplankton are the major producers (Biersmith and Benner, 1998) releasing 5-10\% of the total photosynthetic carbon production under rapid growth conditions, and considerably more under nutrient limited growth, because carbon fixation may exceed incorporation into cell material (Carlson, 2002). DOC production is also influenced by the phytoplankton community composition (Biddanda and Benner, 1997) and is greatly enhanced by grazing of protists and copepods (Strom et al., 1997). Biological release of DOC and DON during field experiments has been reported for different types of marine waters (Karl et al., 1998; Bronk and Glibert, 1993; Bronk and Glibert, 1994; Bronk et al., 1994; Raimbault et al., 1999b; Fernandez and Raimbault, 2007). In a tightly coupled system with a rapid turnover, a fraction of this DOC is labile and will fuel heterotrophic and photo-heterotrophic production. But, over longer time scales, biological production and accumulation of DOC and DON seem to be evident in oceanic regions (Avril, 2002; Libby and Wheeler, 1997), processes which would be favoured by nutrient depletion (Kähler and Koeve, 2001). In seasonal studies of the dynamics of inorganic and organic nitrogen, Buttler et al. (1979), Maita and Yanada (1990) and Libby and Wheeler (1997) found an inverse relationship between nitrate concentration and DON in the English channel, the sub arctic Pacific water, and in the Equatorial Pacific, respectively. Zweifel et al. (1993) showed that the addition of nutrients to samples from a nutrientdepleted system promoted DOC breakdown, which also implies that the lack of nutrients favours DOC preservation. Cauwet et al. (2002) reported that during nutrient deficiency, bacteria are unable to utilize a carbon-rich organic substrate like carbohydrates. Therefore as suggested by Thingstad et al. (1997) and Tanaka and Rassoulzadegan (2002), this surface accumulated DOC could indicate long term mal- functioning of the microbial loop; this could be related to bacteria-phytoplankton competition for inorganic nutrients that reduce DOC remineralization in nutrient-depleted water.

According to Eppley and Peterson (1979), annual new production must balance the organic particle flux from the euphotic zone to the deep waters. Thus, particulate export in the sea is traditionally considered to vary with new production, increasing with the input of nitrate from deep waters that penetrates through the nitracline. Under ecological conditions where large amounts of DOM are produced in response to inorganic nutrient limitation, such as those described in this study, the traditional particulate matter biological pump may be completed with the export of dissolved matter (Copin-Montégut and Avril, 1993; Carlson et al., 1994; Toggweiller, 1989). Several studies in oceanic environments have shown DOC accumulation over the productive period in the upper water column where it is homogenized. This DOC, accumulates from summer to autumn, then disappears from the surface layer during destratification and winter mixing (Copin-Montegut and Avril, 1993; Carlson et al., 1994). Except some Ekman wind-driven circulation which can lead to lateral transport of significant part of DOM (Roussenov et al., 2006; Mahaffey et al., 2004), horizontal advection can be neglected in the centre of the SPG that can be considered as at rest. Intense seasonal convective mixing is excluded enabling the SPG to maintain high DOC concentrations and act as a large and a long-term reservoir of biological carbon. Another route for DOC transfer is via the diffusive mode, which could persist in this permanent stratified water. Assuming that nutrient flux (inorganic or inorganic) in or out of the mixed layer is linearly correlated to the gradient $\left(\delta\right.$ nutrient $/ \delta \mathrm{z}$, units $\left.=\mu \mathrm{molm}^{-4}\right)$ from the bottom of the mixed layer by a vertical diffusion coefficient $(K z$; units $=\mathrm{m}^{2} \mathrm{~d}^{-1}$, we can calculate the diffusive vertical fluxes ( $F_{\text {nutrients }}$; units $\mu \mathrm{molm}^{-2} \mathrm{~d}^{-1}$ ) using the following equation: $F_{\text {nutrient }}=K z \delta_{\text {Nutrient }} / \delta \mathrm{z}$.

$K z$ is the diffusion coefficient obtained from the following equation: $K z=0.24 \varepsilon / \mathrm{N}^{2}$, where $\varepsilon$ (units, $\mathrm{m}^{-2} \mathrm{~s}^{-3}$ ) is the turbulent kinetic energy dissipation and $\mathrm{N}$ (units, $\mathrm{s}^{-1}$ ) is the buoyancy (Brünt-Väisälä) frequency (Oakey, 1982). Values for $\varepsilon$ as well as for $K z$ are rarely experimentally available, especially in oceanic waters. However, assuming the only nitrate source for phytoplankton growth comes from deep water via turbulent diffusion, we can propose that the biological nitrate uptake is equal to this diffusive flux, as suggested by King and Devol (1979). Using integrated nitrate uptake rates measured in the SPG $\left(60 \mu\right.$ moles $\mathrm{m}^{-2} \mathrm{~d}^{-1}$; Raimbault and Garcia, 2007) and nitrate gradients from the top of the thermocline $\left(75.4 \pm 22 \mu\right.$ moles $\left.\mathrm{m}^{-4}\right)$, the $K z$ value is estimated $\left(0.76 \pm 0.81 \mathrm{~m}^{2} \mathrm{~d}^{-1}=0.09 \pm 0.1 \mathrm{~cm}^{2} \mathrm{~s}^{-1}\right)$. This value agrees with previous results obtained from oceanic waters (Eppely et al., 1979; King and Devol; 1979; Lewis et al., 1986) ranging from 0.06 to $0.75 \mathrm{~cm}^{2} \mathrm{~s}^{-1}$. The diffusive fluxes of inorganic and organic dissolved nutrients in the SPG calculated using this $K z$ value, are presented in 
Table 3. Turbulent fluxes for DOC, DON and DOP are estimated to be 134,5 and $0.3 \mu$ moles $\mathrm{m}^{-2} \mathrm{~d}^{-1}$, respectively. These DOC and DON fluxes were equivalent to the particle flux measured simultaneously, using drifting sediment traps placed just below the photic zone (12-96 $\mu$ moles $\mathrm{C} \mathrm{m}^{-2} \mathrm{~d}^{-1}$; 2.8-14 $\mu$ moles $\mathrm{N} \mathrm{m}^{-2} \mathrm{~d}^{-1}$, J. C. Miquel, personal communication). When considering the mean primary production in the SPG $\left(0.15 \mathrm{~g} \mathrm{~m}^{-2} \mathrm{~d}^{-1}\right.$; Raimbault and Garcia, 2007), this calculated downward DOC flux represents a low proportion of the total primary production $(\approx 2 \%)$, but a large fraction $(34 \%)$ of the new production as calculated from integrated nitrate uptake $\left(60 \times 6.6=396 \mu\right.$ moles $\left.\mathrm{C} \mathrm{m}^{-2} \mathrm{~d}^{-1}\right)$. Assuming these values are constant throughout the year, we can deduce an annual diffusive export of $0.44 \mathrm{gC} \mathrm{m}^{-2} \mathrm{y}^{-1}$, a lower value than that obtained by Avril (2002) for the Mediterranean sea during the oligotrophic stratified pe$\operatorname{riod}\left(1 \mathrm{~g} \mathrm{C} \mathrm{m}^{-2} \mathrm{y}^{-1}\right)$. Global DOC export (vertical mixing+turbulent mixing) is estimated to be $1.7 \mathrm{GT} /$ year (Six and Maier-Reimer, 1996), a value consistent with the oceanic "missing" $\mathrm{CO}_{2}$ sink quantified to be about $1.8 \mathrm{GTC}^{-y^{-1}}$ (Siegenthaler and Sarmiento, 1993). According to Avril (2002) about $10 \%\left(170^{*} 10^{6} \mathrm{~T} / \mathrm{y}^{-1}\right)$ of this global DOC export could be due to diffusion processes. The diffusive export of the entire South Pacific gyre, representing $1.1 \%$ of the global oceanic surface $\left(4.10^{6} \mathrm{~km}^{2}\right)$, is estimated to be about $2.510^{6} \mathrm{TC}$ and could represent about $1.5 \%$ of the global DOC diffusive flux. Assuming DOC release rates are 4 to $10 \%$ of gross production, levels generally reported in the literature (Mingelbier et al., 1994) and a $2 \%$ loss by diffusion (see above), the excess DOC in the centre of the SPG $\left(10000\right.$ mmoles $\left.\mathrm{C} \mathrm{m}^{-2}=120 \mathrm{~g} \mathrm{C} \mathrm{m}^{-2}\right)$ would correspond to an accumulation over a period of 41 to 124 years. Therefore our present calculation suggests a significant role of the SPG in the global biogeochemical budget of carbon, for (1) long-term storage in surface waters and (2) significant export to deep water.

\section{Conclusions}

As expected from satellite imagery, the South Pacific Gyre (SPG) transected by the BIOSOPE cruise, is a very oligotrophic area characterized by a strong depletion of inorganic nitrogen and very low phytoplanktonic biomass. The distribution of hydrological parameters and inorganic nutrients clearly showed that the organic parameters (particulate or dissolved) varied much less than might be expected from nutrient distributions. The most important feature observed was the large accumulation of dissolved organic matter, reflecting the specific functioning of the productivity system and the biological $\mathrm{CO}_{2}$ pump. The SPG can store and preserve a large quantity of low-N organic material in the photic layer. The surface waters of the SPG, once described as a "monotonous and unchanging oceanic desert" (Claustre and Maritorena, 2003), could be home to a dynamic ecosystem exhibiting high accumulation of carbon-rich dissolved organic matter. The concept of new production and the Redfield constant appears to be strongly influenced by carbon dynamics and was not linearly coupled with that of nitrogen. Moreover, assuming that there is no real steady-state for carbon cycling, a large quantity of atmospheric carbon, fixed by photosynthesis, can ultimately be accumulated over long periods in the surface layer and not immediately exported. Consequently understanding both the DOC production rates and the chemical composition of this accumulated pool is essential before accurate biogeochemical and metabolic models can be formulated for this ultra-oligotrophic system of the South Pacific Gyre.

Acknowledgements. This is a contribution of the BIOSOPE project of the LEFE-CYBER program, funded by the Centre National de la recherche Scientifique (CNRS), the Institut des Sciences de l'Univers (INSU), the Centre National d'Etudes Spatiales (CNES), The European Space Agency (ESA), the National Aeronautics and Space Administration (NASA) and the natural Sciences and Engineering Research Council of Canada (NSERC). This work is fund in part by the French Research and Education Council. The Biosope cruise program was managed by $\mathrm{H}$. Claustre and A. Sciandra. We thank the crew of the R/V Atalante for outstanding shipboard support operations. Data concerning Euphotic Layer Depths was kindly provided by H. Claustre and J. Ras. D. Taillez and C. Bournot are thanked for their efficient help in CTD rosette management and data processing, as is J. C. Miquel for providing particulate samples from an in situ pump. The authors gratefully thank the two anonymous referees who helped to make substantial improvements in the manuscript and T. Bentley for her linguistic and scientific advice.

Edited by: S. Pantoja

\section{References}

Altabet, M.: Organic C, N and stable isotopic composition of particulate matter collected on glass-fibre and aluminium oxide filters, Limnol. Oceanogr., 35, 902-909, 1990.

Altabet, M. A. and McCarthy, J. J.: Vertical patterns in ${ }^{15} \mathrm{~N}$ natural abundance in PON from the surface waters of warm-core rings, J. Mar. Res., 44, 203-225, 1986.

Andrié, C., Bouloubassi, I., Cornu, H., Fichez, R., Pierre, C., and Rougerie, F.: Chemical tracer studies in coral reef interstitial waters (French Polynesia), Implications for endo-upwelling circulation, in: Proceedings of the 7th Coral Reef International Symposium, edited by: Richmond, R. H., Univ of Guam press, 11651173, 1993.

Armstrong, F. A. J., Stearns, C. R., and Strickland, J. D. H. : The measurement of upwelling and subsequent biological processes by means of the Technicon AutoAnalyzer and associated equipment, Deep-Sea Res., 14(3), 381-389, 1967.

Avril, B.: DOC dynamics in the northwestern Mediterranean Sea (DYFAMED Site), Deep-Sea Res., 49, 2163-2182, 2002.

Biddanda, D. and Benner, R.: Carbon, nitrogen and carbohydrate fluxes during the production of particulate and dissolved organic 
matter by marine phytoplankton, Limnol. Oceanogr., 42, 506518, 1997.

Biersmith, A. and Benner, R.: Carbohydrates in phytoplankton and freshly produced dissolved organic matter, Mar. Chem., 63, 131144, 1988.

Brzezinski, M. A.: Vertical distribution of ammonium in stratified oligotrophic waters, Limnol. Oceanogr., 33, 1176-1182, 1988.

Brandhorst, W.: Nitrite accumulation in the north-east tropical Pacific, Nature, London, 182, 679, doi:10.2038/182179aO, 1958.

Bronk, D. A. and Glibert, P. M.: Application of a $15 \mathrm{~N}$ tracer method to the study of dissolved organic nitrogen uptake during spring and summer in Chesapeake Bay, Mar. Biol., 115, 501-508, 1993.

Bronk, D. A. and Glibert, P. M.: The fate of missing ${ }^{15} \mathrm{~N}$ differs among marine systems, Limnol. Oceanogr., 39, 189-194, 1994.

Bronk, D. A., Glibert, P. M., and Ward, B. B.: Nitrogen uptake, dissolved organic nutrient release and new production, Science, 256, 1843-1846, 1994.

Butler, E. I., Knox, S., and Liddcoat, M. I.: The relationship between inorganic and organic nutrients in seawater, J. Mar. Biol. Assoc. UK, 59, 239-250, 1979.

Carlson, C. A.: Production and removal processes, in: Biogeochemistry of marine dissolved organic matter, edited by: Hansell, D. A. and Carlson, C.A., Academic press, Amsterdam, 91-151, 2000.

Carlson, C. A., Ducklow, H. W. and Michaels, A. F.: Annual flux of dissolved organic carbon from theeuphotic zone in thenorthwestern Sargasso Sea, Nature, 371, 405-408, 1994.

Carr, M. E.: Estimation of potential productivity in eastern boundary current using remote sensing, Deep-Sea Res. Pt. II, 49, 5980, 2002.

Cauwet, G., Déliat, G., Krastev., A., Shtereva, G., Becquevort, S., Lancelot, C., Momzikoff, A., Saliot, A., Cociasu, A., and Popa, L.: Seasonal DOC accumulation in Black Sea: a regional explanation for a general mechanism, Mar. Chem., 79, 193-205, 2002.

Chavez, F. P., Buck, K. R., Bidigare, R. R., Karl, D. M., Hebel, D., Latasa, M., and Campbell, L.: On the chlorophyll $a$ retention properties of glass-fiber GF/F filters, Limnol. Oceanogr., 40, 428-433, 1995.

Chekley, D. M. and Miller, C. A.: Nitrogen isotope fractionation by oceanic zooplankton, Deep-Sea Res., 36, 1449-1456, 1989.

Church, M. J., Ducklow, H. W., and Karl, D. M.: Multiyear increases in dissolved organic mater inventories at station ALOHA in the North pacific subtropical gyre, Limnol. Oceanogr., 47, 110, 2002.

Clark, L., Ingall, E. D., and Benner, R.: Marine organic phosphorus cycling: Novel insights from nuclear magnetic resonance, Am. J. Sci., 2999, 724-737, 1999.

Claustre, H. and Maritorena, S.: Ocean Science: The many shades of ocean blue, Science, 302, 1514-1515, 2003.

Claustre, H., Sciandra, A., and Vaulot, D.: Introduction to the special section: bio-optical and biogeochemical conditions in the South east Pacific late 2004 - the BIOSOPE cruise, Biogeosciences Discuss., 5, 605-640, 2008,

http://www.biogeosciences-discuss.net/5/605/2008/.

Cline, J. D. and Kaplan, I. R.: Isotopic fractionation of dissolved nitrate during denitrification in the eastern tropical North Pacific Ocean, Mar. Chem., 3, 271-299, 1975.
Copin-Montégut, G. and Avril, B.: Vertical distribution and temporal varaition of dissolved organic carbon in the North-Western Mediterranean Sea, Deep-Sea Res., 40, 1963-1972, 1993.

Copin-Montégut, C. and Copin-Montégut, G.: The chemistry of particulate matter from the south indian and Antarctic oceans, Deep-Sea Res., 25, 911-931, 1978.

Dandonneau, Y., Montel, Y., Blanchot, J., Giraudeau, J., and Neveux, J.: Temporal variability in phytoplankton pigments, picoplankton and coccolithophores along a transect through the North Atlantic and tropical southwestern pacific, Deep-Sea Res. Pt. I, 53, 689-712, 2006.

Daneri, G. and Quinones, R. A.: Undersamples ocean systems: appeal for an international study of biogeochemical cycles in the Southern Pacific gyre and its boundaries, U.S. JGOFS Newsletter January 2001: 9, 2001.

Denman, K. L. and Gargett, A. E.: Time and space scales of vertical mixing and advection of phytoplankton in the upper ocean, Limnol. Oceanogr., 28, 801-815, 1983.

Deutsch, C., Gruber, R., Key, R. M., Sarmiento, J. L., and Ganachaud, A.: Denitrification and N2 fixation in the Pacific ocean, Global Biogeochem. Cy., 15, 483-506, 2001.

Dickson, M. L. and Wheeler, P. A.: Chlorophyll a concentrations in the north pacific: Does a latitudinal gradient exist?, Limnol. Oceanogr., 38, 1813-1818, 1993.

Dore, J. E., Brum, J. R., Tupas, L. M., and Karl, D. M.: Seasonal and interannual variability in sources of nitrogen supporting export in the oligotrophic subtropical North pacific Ocean, Limnol. Oceanogr., 47, 1595-1607, 2002.

Eppley, R. C., Chavez, F. and Barber R.: Standing stocks of particulate carbon and nitrogen in the Equatorial Pacific at $150^{\circ} \mathrm{W}, \mathrm{J}$. Geophys. Res., 97, 655-661, 1992.

Eppley, R. W., Garside, C., Renger, R. W., and Orellana, E.: Variability of nitrate concentration in nitrogen-depleted subtropical surface waters, Mar. Biol., 107, 53-60, 1990.

Eppley, R. W. and Peterson, B. J.: Particulate organic matter flux and planktonic new production in the deep ocean, Nature, 282, 677-680, 1979.

Eppley, R. W., Renger, E. G., and Harrison, W. G.: Nitrate and phytoplankton production in southern California coastal waters, Limnol. Oceanogr., 24, 483-494, 1979.

Faul, K. L., Paytan, A., and Delaney, M. L.: Phosphorus distribution in sinking oceanic particulate matter, Mar. Chem., 97, 307-333, 2005.

Fernandez, C. and Raimbault, P.: Nitrogen regeneration in the NE Atlantic Ocean and its impact on seasonal new, regenerated and export production, Mar. Ecol.-Prog. Ser., 337, 79-92, 2007.

Fleming, R. H.: The composition of plankton and units for reporting population and production, 6th Pacific Science Congress, 5, 535540, 1940.

Garside, C.: A chemoluminescent technique for the determination of nanomolar concentrations of nitrate and nitrite in seawater, Mar. Chem., 11, 159-167, 1982.

Garside, C.: The vertical distribution of nitrate in open ocean water, Deep-Sea Res., 32, 723-732, 1985.

Grob, C., Ulloa, O., Claustre, H., Alarcon, G., Huot, Y., and Marie, D.: Contribution of picoplankton to the particulate attenuation coefficient (cp) and organic carbon concentration (POC) in the eastern South pacific, Biogeosciences, 4, 837-852, 2007, http://www.biogeosciences.net/4/837/2007/. 
Holmes, M. R., Aminot, A., Kerouel, R., Hooker, B. A., and Peterson, J. B.: A simple and precise method for measuring ammonium in marine and freshwater ecosystems, Can. J. Fish. Aquat. Sci., 56, 1801-1808, 1999.

Hoch, M. M. P., Fogel, M. L., and Kirchman, D. L.: Isotope fractionation associated with ammonium uptake by marine bacterium, Limnol. Oceanogr., 37, 1447-1459, 1992.

Hansell, D. A. and Carlson, C. A.: Deep ocean gradients in the concentration of dissolved organic carbon, Nature, 395, 263-266, 1998.

Jickells, T. D., An, Z. S., Andersen, K. K., et al.: Global iron connections between desert dust, ocean biogeochemistry and climate, Science, 30, 67-71, 2005.

Kähler, P. and Koeve, W.: Marine dissolved organic matter: can its $\mathrm{C}: \mathrm{N}$ ratio explain carbon over consumption?, Deep-Sea Res. Pt. I, 48, 49-62, 2001.

Karl, D. M.: Nutrients dynamics in the deep blue sea, Trends Microbiol., 10, 410-418, 2002.

Karl, D. M., Tien, G., Dore, J., and Winn, D.: Total dissolved nitrogen and phosphorus concentrations at US-JGOFDS Station ALOHA: Redfield reconciliation, Mar. Chem., 41, 203-208, 1993.

Karl, D. M. and Tien, G.: Temporal variability in dissolved phosphorus concentrations in the subtropical North Pacific Ocean, Mar. Chem., 56, 77-96, 1997.

Karl, D. M., Hebel, D. V., and Björkman, K.: The role of dissolved organic matter release in the productivity of the oligotrophic North Pacific Ocean, Limnol. Oceanogr., 43, 1270-1286, 1998.

Kepkay, P. E. and Wells, M. L.: Dissolved organic carbon in the North Atlantic surface waters, Mar. Ecol.-Progr. Ser., 80, 275283, 1992.

King, F. D. and Devol, A. H.: Estimates of vertical eddy diffusion through the thermocline from phytoplankton nitrate uptake rates in the mixed layer of the eastern pacific, Limnol. Oceanogr., 24, 645-651, 1979.

Kirkwood, D. S.: Stability of solutions of nutrients salts during storage, Mar. Chem., 38, 151-164, 1992.

Law, E. A, DiTullio, G. R., Betzer, P. R., Karl, D. M. and Carder, K. L.: Autotrophic production and elemental fluxes at $26^{\circ} \mathrm{N}$, $155^{\circ} \mathrm{W}$ in the north pacific subtropical gyre, Deep-Sea Res., 36, 103-120, 1987.

Lewis, M. R., Harrison, W. G., Oakey, N. S., Hebert, D., and Platt, T.: Vertical nitrate fluxes in the oligotrophic ocean, Science, 234, 870-872, 1986.

Libby, P. S. and Wheeler, P. A.: Particulate and dissolved organic nitrogen in the central and eastern Equatorial Pacific, Deep-Sea Res., 44, 345-361, 1996.

Liu, K. K. and Kaplan, I. R.: The eastern tropical north Pacific as a source of ${ }^{15} \mathrm{~N}$-enriched nitrate in seawater off Southern California, Limnol. Oceanogr., 34, 820-830, 1989.

Lomas, M. W. and Lipschultz, F.: Forming the primary nitrite maximum: nitrifiers or phytoplankton?, Limnol. Oceanogr., 51, 24532467, 2006.

Longhurst, A. R.: Ecological geography of the Sea, Academic press, London, 398 pp., 1998.

Mahaffey, C., Williams, R., and Wolf, G.: Physical supply of nitrogen to phytoplankton in the Atlantic Ocean, Global Biogeochem. Cy., 18, GB1034, doi:10.1029/2003GB002129, 2004.
Maita, Y. and Yanada, M.: Vertical distribution of total dissolved nitrogen and dissolved organic nitrogen in seawater, Geochemical J., 24, 245-254, 1990.

McCarthy, J. I.: Nitrogen and phytoplankton ecology, in: The physiological ecological y of phytoplankton, edited by: Morris, I., Blackwell, 191-233, 1980.

Menzel, D. W. and Ryther, J. H.: The composition of particulate organic matter in the western north Atlantic, Limnol. Oceanogr., 9, 179-186, 1964.

Minagawa, M. and Wada, E. Z.: Nitrogen isotopes ratios of red tide organisms in the east China Sea: A characterization of biological nitrogen fixation, Mar. Chem., 19, 245-259, 1984.

Mingelbier, A., Klein, B., Claereboudt, R., and Legendre, L.: Measurement of daily primary production using $24 \mathrm{~h}$ incubations with the 14C method: a caveat, Mar. Ecol.-Progr. Ser., 113, 301-309, 1994.

Montoya, J. P. and McCarthy, J. J.: Isotopic fractionation during nitrate uptake by phytoplankton grown in continuous culture, J. Plankton Res., 17, 439-464, 1995.

Morel, A. and Maritorena, S.: Bio-optical properties of oceanic waters: a reappraisal, J. Geophys. Res., 106(C4), 7163-7180, 2001.

Morel, A., Gentili, B., Claustre, H., Babin, M., Bricaud, A., Ras, J., and Tieche F.: Optical properties of the clearest natural waters, Limnol. Oceanogr., 52, 217-229, 2007.

Oakey, N. S.: Determination of the rate of dissipation of turbulent energy from simultaneous temperature and velocity shear microstructure measurements, J. Phys. Oceanogr., 12, 256-271, 2002.

Olson, R. J.: Differential photoinhibition od marine nitrifying bacteria: a possible mechanism for the formation of the primary nitrite maximum, J. Mar. Res., 39, 227-238, 1981.

Raimbault, P.: Effect of temperature on nitrite excretion by three marine diatoms during nitrate uptake, Mar. Biol., 92, 149-155, 1986.

Raimbault, P. and Garcia, N.: Carbon and nitrogen uptake in the South Pacific Ocean: Evidence for efficient dinitrogen fixation and regenerated production leading to large accumulation of dissolved organic matter in nitrogen-depleted waters, Biogeosciences Discuss., 4, 3531-3579, 2007,

http://www.biogeosciences-discuss.net/4/3531/2007/.

Raimbault, P., Slawyk, G., Coste, B., and Fry, J.: Feasibility of using an automated colorimetric procedure for the determination of seawater nitrate in the 0 to $100 \mathrm{nM}$ range: Examples from field and culture. Mar. Biol., 104, 347-351, 1990.

Raimbault, P., Pouvesle, W., Sempéré, R., Diaz F., and Garcia, N.: A simple procedure for simultaneous analysis of total and dissolved organic forms of carbon, nitrogen and phosphorus in seawater using the wet-oxidation technique, Mar. chem., 66, 161169, 1999.

Raimbault, P., Diaz, F., and Boudjellal, B.: Simultaneous determination of particulate forms of carbon, nitrogen and phosphorus collected on filters using a semi-automatic wet-oxidation procedure, Mar. Ecol.-Progr. Ser., 180, 289-295, 1999.

Raimbault, P., Slawyk, G., Boudjellal, B., Coatanoan, C., Conan, P., Coste, B., Garcia, N., Moutin, T., and Pujo-Pay, M.: Carbon and nitrogen uptake and export in the equatorial pacific at $150^{\circ} \mathrm{W}$ : Evidence of an efficient regenerated production cycle, J. Geophys. Res., 104(C2), 3341-3356, 1999. 
Raimbault, P., Slawyk, G., and Garcia, N.: Comparison between chemical and isotopic measurements of biological nitrate utilization: further evidence of low new production levels in the equatorial Pacific, Mar. Biol., 136, 1147-115, 2000.

Raimbault, P., Neveux, J. and Lantoine, F. : Dosage rapide de la chlorophylle $a$ et des phaeopigments $a$ par fluorimétrie après extraction au méthanol, Comparaison avec la méthode classique d'extraction à l'acétone, Oceanis, 30(2), 189-205, 2004.

Ras, J., Claustre, H., and Uitz, J.: Spatial variability of phytoplankton pigment distributions in the subtropical South pacific Ocean: a comparison between in situ and modelled data, Biogesciences Discuss., 4, 3409-3451, 2007.

Redfield, A. C., Ketchum, B. H., and Richards, F. A.: The influence of organisms on the composition of seawater, in: The Sea Wiley, edited by: Hill, M. N., 26-77, 1963.

Roussenov, V., Williams, R. G., Mahaffey, C., and Wolff, G. A.: Does the transport of dissolved organic nutrients affect export production in the Atlantic Ocean?, Global Biocheochem. Cy., 20, GB3002, doi:101029/2005GB002510, 2006.

Sahlsten, E.: Nitrogen nutrition in the euphotic zone of the central north Pacific gyre, Mar. Biol., 96, 433-439, 1987.

Siegenthaler, U. and Sarmiento, J. L.: Atmospheric carbon dioxide and the ocean, Nature, 365, 119-125, 1993.

Signorini, S. R., McClain, C. R., and Dandonneau, Y.: Mixing and phytoplankton bloom in the wake of Marquesas Islands, Geophys. Res. Lett., 26, 3121-3214, 1999.

Six, K. D. and Maier-Reimer, E.:. Effects of plankton dynamics on seasonal carbon fluxes in an ocean general circulation model, Global Biogeochem. Cy., 10(4), 559-583, 1996.

Smith, S. V.: Phosphorus versus nitrogen limitation in the marine environment, Limnol. Oceanogr., 29, 1149-1160, 1983.

Strom, S. L., Benner, R., Ziegler, S., and Magg, M. J.: Planktonic grazers are potentially important source of marine dissolved organic carbon, Limnol. Oceanogr., 42, 1364-1374, 1997.

Tanaka, T. and Rassoulzadegan, F.: Full-depth profile $(0-2000 \mathrm{~m})$ of bacteria, heterotrophic nanoflagellates and ciliates in the NW Mediterranean Sea: Vertical partitioning of microbial trophic structures, Deep-Sea Res., 49, 2093-2107, 2002.

Thingstad, T. F., Hagstrom, A., and Rassoulzadegan, F.: Accumulation of degradable DOC in surface waters: is it cause by malfunctionning microbial loop?, Limnol. Oceanogr., 42, 398-404, 1997.
Toggeweiler, J. R.: Is the downward dissolved organic matter (DOM) flux important in carbon export, in: Productivity of the ocean: Present and past, edited by: Berger, W. H., Smetacek, V. S., and Wefer, G., Wiley-Intersci., New-York, 65-84, 1989.

Tréguer, P. and LeCorre, P.: Manuel d'analyses des sels nutritifs dans l'eau de mer: Utilisation de l'Autoanalyser II Technicon, Univ. of Bretagne Occidentale, Lab. de Chim. Mar., Brest, France, 1975.

Tyrrell, T.: The relative influence of nitrogen and phosphorus on oceanic primary production, Nature, 400, 525-531, 1999.

Vaccaro, R. F. and Ryther, J. H.: Marine phytoplankton and the distribution of nitrite in the sea, J. Cons. Perm. Int. Explor. Mer, 26, 260-271, 1960.

Voituriez, B. and Herbland, A.: Production primaire, nitrate, nitrite dans l'Atlantique tropical, II Distribution du nitrate et production du nitrite, Cah. ORSTOM, Sér. Océanogr., 15, 57-66, 1997.

Wada, E. and Hattori, A.: Nitrite metabolism in the euphotic zone of the central Pacific Ocean, Limnol. Oceanogr., 16, 766-772, 1971.

Wada, E. and Hattori, A.: Natural abundance of $15 \mathrm{~N}$ in particulate organic matter in the North Pacific Ocean, Geochim. Cosmochim. Ac., 40, 249-251, 1976.

Ward, B. B., Kilpatrick, K. A., Renger, E., and Eppley, R. W.: Biological cycling in the nitracline, Limnol. Oceanogr., 34, 493-513, 1989.

Waser, N. D. A., Harrison, W. C., Head, E.J.H., Nielsen, B., Lutz, V. A., and Calvert, S. E.: Geographic variations in the nitrogen isotope composition of surface particulate nitrogen and new production across the North Atlantic Ocean, Deep-Sea Res., 47, 1207-1226, 2000.

Welschmeyer, N. A.: Fluorometric analysis of chlorophyll $a$ in the presence of chlorophyll $b$ and pheopigments, Limnol. Oceanogr., 39(8), 1985-1992, 1994.

Williams, P. J. le B.: Biological and chemical aspects of dissolved material in sea water, in: Chemical Oceanography, 2nd Edition, Vol. 2, edited by: Riley, J. P. and Skirrow, G., Academic Press London, 301-362, 1975.

Zweifel, U. L., Norrman, B., and Hagstrom, A.: Consumption of dissolved organic carbon by bacteria and demand for inorganic nutrients, Mar. Ecol.-Prog. Ser., 101, 23-32, 1993. 